\title{
Karabağ'daki Hocalı Soykırımının Tarihi Arka Planı
}

\section{İsmail Özçelik ${ }^{*}$}

\section{Özet}

Karabağ Hanlığının kurucusu Penah Ali Handır. Penah Ali Bey göçebe hayat süren Cevanşir Türkmenlerinden olup Sarıcalı oymağına mensuptur. Önceleri İran hükümdarı Nadir Şah'ın hizmetinde bulunmuş ve onun emrinde önemli görevler yapmıştır. Fakat İran sarayında kendisi gibi görev alan kardeşinin Nadir Şah tarafından idam edilmesi nedeniyle Karabağ’a gitmiş ve İran hükümdarına karşı bağımsızlık mücadelesine girişmiştir. Karabağ hanlığının kurulması da bu mücadelenin neticesine dayanmaktadır. 1749 yılında hanlığını ilan eden Penah Ali Han, vefatından sonra yerine oğlu ỉbrahim Halil Han geçmiştir 1806 yılında yerine halefi Mehdi kulu Han Karabağ hanlığına hükümdar olmuş ve bu durum 1822 yılında Rus istilasının gerçekleşmesine kadar sürmüştür.

Penah Ali Han, Karabağ'da Şuşa şehrini kendine başkent edinmiş ve bu şehre Penahabad ismi verilmiştir. Kendi adına sikke de bastıran Penah Ali Han'ın bu sikkelerine "Penahabadi" adı verilmiştir. Nadir Şah'ın ölümünden sonra onun komutanlarından olan Urmiyeli Fetih Ali Han Avşar, devlet kurma iddiasıyla Urmiye vilayetinde harekete geçerek Azerbaycan'ı fethetmek istemiş ve Pehah Ali Han'a elçiler ve değerli hediyeler göndererek, onunla ittifak yapmak istemiştir.

Ibrahim Halil Han'ın Karabağ'daki saltanat dönemine bakıldığında Rusya'nın yayılmacılığa başladığı ve İran da taht kavgalarının şiddetlendiği bir dönem yaşanmıştır. Bu dönemde Şuşha ve Karabağ ibrahim Han'ın yardım alamaması nedeniyle ve bazı hanların Ruslara tabi olması sonucunda Ibrahim Halil Han Osmanlı Devleti'nden yardım talebinde bulunmuş, Rusya ile ittifak kuran Tiflis Hanı Iraklı Han da Osmanlı Devleti ile dost olmak istemiştir. Osmanlı devletinin zayıflaması ve duraklamaya girmesi sırasında Kafkasya da başlayan Rus yayılmacılığı ve İran politikaları bu coğrafyada Türk Hanlıklarının bağımsızlıklarının sona ermesiyle sonuçlanan süreçte, Revan Hanlığının Erivan şekline dönüşmesi ve Ermenistan devletinin teşekkülüne zemin hazırlanmıştır. Bununla birlikte Karabağ Meselesi ve Ermenistan ile Azerbaycan arasındaki ayrılıkların da tohumları ekilmiştir. İşte Hocalı Katliamı bu tarihi gelişmelerin eseridir.

Prof. Dr., Kırıkkale Üniversitesi, Fen-Edebiyat Fakültesi, Tarih Bölümü, iozcelik6@gmail.com. (ORCID ID: 0000-0002-8446-9900).

(Makale Gönderim Tarihi: 19.06.2017, Makale Kabul Tarihi: 20.08.2017).

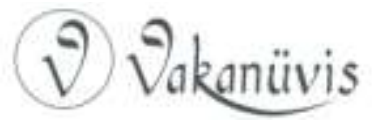


Anahtar Kelimeler: Karabağ Hanlığı, İbrahim Halil Han, Penah Halil Han, Şuşa, Penahabad, Hocalı

\title{
The Historical Background of the Hocalı Genocide in Karabagh
}

\begin{abstract}
Penah Ali Khan was the founder of Karabagh Khanate. Penah Ali was a member of Cevanşir Turcoman's Saricali Tribe which lives a nomadic life. Previously he had been under the service of Nadir Şah and occupied important positions. After execution of his brother by Nadir Şah he went to Karabagh and gave struggle against Nadir Şah. Establishment of Karabagh Khanate lies on this struggle. He declared himself as Khan in 1749, after his dead son of him İbrahim Halim became the khan. Predecessor of him was Mehdi Kulu and his khanate went on till Russian occupation in 1822.

Susha city of Karabagh was capital of Penah Ali Khan, the city called also as Penahabad. He coined named Penahabadi. After dead of Nadir Şah, one of his commander Fetih Ali Khan from Urmiye occured by the idea of new state in the region. He sent some valuable gifts and wished be in alliance with Penah Ali Khan.

His reign was duration of struggles of throne in İran and Russian occupations. By the reason of Ibrahim Kkan could not have help some khans became subject to Russia. In this period Ibrahim Khan asked assistance of the Ottoman Empire, Iraklı Khan who took the control in Tiblisi tried to have good relations with Ottoman Sultan. Discontuniation of the Ottoman Empire in this period gave an impetus to Russian occupations and Revan Khanate turned to Erivan and gave a base to Armenian state. Furthermore Karabagh Issue of today between Azarbaycan and Armenia first seen in the region. Hocalı massacre is result of this historical background.
\end{abstract}

Keywords: Karabagh Khanate, İbrahim Halil Khan, Penah Ali Khan, Susha, Penahabad, Hocalı 


\section{Giriş}

Azerbaycan'da Kür ve Aras ırmakları ile Gökçe Göl arasında bulunan ve tarihte "Arran" ${ }^{1}$ diye anılan topraklar içindeki dağlık bölgeye "Karabağ" denilmekte ve burada XVIII. yüzyılda kurulan Türk hanlığı da aynı isimle anılmaktadır. Evliya Çelebi, ünlü Seyahatnamesinde burası için "Küçük Azerbaycan" tabirini kullanmıştır. Bilindiği gibi isimler bir yerin tarihi ve geçmiş hakkında önemli ipuçları verirler. " "Karabağ" isminin bölgedeki yüksek vadilerden ve koyu renkli verimli topraktan geldiği veya "Kara" ile "Bağ" kelimelerinin birleştirilmesiyle ortaya çıktığı iddia edilmektedir. Bundan başka bu ismin Türkçe bir kökten geldiği de açıkça görülmektedir. Bu yörede "Karadağlı, Karakoyunlu, Karademirçilü, Karapirimlü, Karaserkârlü, Karadolak, Karabulak, Karalar, Karadonlu, Karapapaklu, Karahanlu, Karacalu, Karabeylü, Karabayramlu, Karavelilü, Karaçınar" gibi boy ve yer adlarının çokluğu dikkat çekmektedir. Burası Türk tarihi bakımından tarihte genellikle bir askeri garnizon yani karargâhı olmuştur. Örneğin Gürcistan seferinden dönen Selçuklu Sultanı Alparslan burasını 1064 yılında kışlak olarak kullanmıştır. ${ }^{3}$ Sultan Melik Şah ise bu bölgeyi 1086 yılında baştanbaşa iskân etmiştir. ${ }^{4}$

Ebu'l-gâzi Bahadır Han'a göre Karabağ, Oğuz Han'ın üçüncü oğlu olan Yılduz'un büyük oğlu Afşar'ın torunlarından Cevanşir Kabilesinin Sarıcalu Sülalesine ait olmuştur. Bu sülale Hülagü Han zamanında Anadolu'ya gelmiş, Timur Anadolu seferi sonrasında bunları Karabağ'a nakledilmiştir. Cevanşir Kabilesinin Sarıcalu sülâlesinin Karabağ'daki köklerinin İslâmlıktan önceki devirlere kadar gittiği bilinmektedir. ${ }^{5}$

\footnotetext{
${ }^{1}$ Arrân Bögesi, Kafkasyada Kura ve Aras nehirleri arasındaki tarihi-coğrafi bölge. Yunan ve Roma dönemlerinde Albanya, Hellenistik Dönem'de Arian ya da Arianoi adlarıyla bilinmekteydi. Bölgenin merkezi Kebele veya Kabala idi. Diğer büyük şehirleriyse Beylagan ve Gence şehirleriydi.

${ }^{2}$ İsmail Özçelik, Tarih ve Metodolojisi, Gazi Kitabevi, Ankara, 2014, s.91-92.

3 Mirza Bala, "Karabağ", İslam Ansiklopedisi, c.6, Milli Eğitim Bakanlığı Yay., İstanbul 1993, s.213.

${ }^{4}$ ibrahim Kafesoğlu, Sultan Melikşah, Kültür Bakanlığı Yayınları, İstanbul, 1973, s.111.

${ }^{5}$ İsmail Özçelik, Karabağ Tarihi ve Karabağ'da Ermeni Olayları, Bilge Yayınları, Ankara, 2003, s.2-3
} 
IIhanlıların yazlık payitahtı Karabağ'daydı. ${ }^{6}$ Bu devirde Moğollarla beraber Karabağ'a gelen ve Müslüman olmayan Göktanrı inancındaki Şamanî Türkler 'in bölgeye yerleşmeye başlamasından sonra, buraya daha önce gelip yerleşmiş ve İslam dinini kabul etmiş olan Türkler, yöreye yeni gelen soydaşlarını Müslümanlaştırmaya çalışmışlardır. Karabağ, Timurlular döneminde de Türkleşmeye devam etmiştir. ${ }^{7}$ Timur, Anadolu seferinden dönerken Karaman, Çukurova ve Suriye'den getirdiği 50. 000 Türkmen ailesinin önemli bir kısmını Karabağ’a yerleştirmiş, burada bazı imar faaliyetlerine girişmiştir. Timur'un kışlak olarak kullandığı Karabağ, Akkoyunlular tarafından da aynı amaçla kullanılmıştır. ${ }^{8}$

Safevîlerin ilk dönemlerinde Karabağ'da Türk unsurunun daha da güçlendiği görülmektedir. Kanuni Devrinde Karabağ ve havalisi Veziriazam Kara Ahmet Paşa tarafından alınmıştır. Kara Ahmet Paşa, Diyarbakır'dan hareketle Erzurum ve Kars üzerinden giderek, Nahcivan, Revan ve Karabağ'ı zapt etmiştir. ${ }^{9}$ Ancak Karabă̆'ın Osmanlı hâkimiyetine kalıcı olarak girmesi III. Murad dönemine rastlar. (15741595). Şirvan ve Bakü'yü ele geçiren Osmanlı kuvvetleri Ferhat ve Cafer Paşaların idaresi altında Karabağ'ı da almışlardır. ${ }^{10}$ (1590) III. Ahmet zamanında (1703-1730), 1720'den sonra, Rusya'nın Hazar Denizi kıyılarını işgal ederek Azerbaycan'a doğru ilerlemesine karşılık, Osmanlı Devleti'nin de harekete geçmesi üzerine iki devlet arasında imzalanan İstanbul Antlaşması sonucunda 1724 yılında Karabağ, Osmanlılar 'da kalmıştır. ${ }^{11}$

Klasik Osmanlı çağında Osmanlılara bağlı olarak Batı Kafkasya bölgesinde dört meliklik vardı. Bunlar, devlete vergi veren ve yarı

\footnotetext{
${ }^{6}$ Zeki Velidi Togan, “Azerbaycan”, İslam Ansiklopedisi, c. 2, Milli Eğitim Bakanlığı Yay., İstanbul, 1993, s. 104.

7 Mustafa Kafalı, "Timur", İslam Ansiklopedisi, c.12, Milli Eğitim Bakanlığı Yay., İstanbul, 1993, s.341.

${ }^{8}$ Mirza Bala, a.g.m., s. 213.

${ }^{9}$ İsmail Hakkı Uzunçarşılı, Osmanlı Tarihi, Cilt 2, Türk Tarih Kurumu Yay., Ankara,1972, s.361.

10 İsmail Hakkı Uzunçarşılı, Osmanlı Tarihi, Cilt. 3, Türk Tarih Kurumu Yay., Ankara,1972, s.62-65.

${ }^{11}$ Uzunçarşıll, a.g.e., c.3, s.65.
}

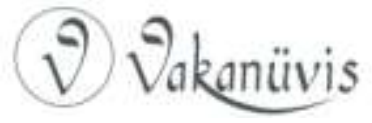


bağımsız Dadyan, Güril, Açıkbaş ve Abaza Meliklikleridir. ${ }^{12}$ Osmanlı idaresi bu meliklikleri bölgedeki Çıldır Beylerbeyliği vasıtasıyla kontrol altında tutmaktaydı. Çıldır Beylerbeyliği, ocaklık suretiyle, yani aynı aileye mensup olan Beylerbeyi tarafından idare edilen hudut eyaletlerinden biriydi. Çıldır Beylerbeyi, bu meliklikleri murakabe altında bulundurur ve aynı zamanda bunların Kafkas ve İran ile olan münasebetleri hakkında Osmanlı Devleti'ni haberdar ederdi. ${ }^{13}$ Çıldır ve Erzurum Beylerbeyliği yakınçağlarda hanlıklarla Osmanlı Devleti arasındaki ilişki ve kontrolü sağlamışlardır.

\section{Karabağ Hanlığının Kuruluşu, Penah Ali Han Dönemi ve İran İle Olan Mücadelesi}

Karabağ Hanlığının kurucusu Penah Ali Bey'dir. Ali Bey, Karabağ'da göçebe hayat süren Cevanşir Türkmenlerinden olup, Sarıcalı oymağındandır. Başlangıçta Nadir Şah'ın hizmetinde yer almış ve kendisine önemli görevler verilmiştir. Ancak, kendisi gibi İran sarayında görev alan kardeşinin, Nadir Şah'ın emriyle idam edilmesi üzerine, Karabağ’a kaçmış ve İran'a karşı bağımsızlık mücadelesine başlamıştır. İşte Karabağ Hanlığının kurulması Penah Ali Bey'in bu dönemdeki faaliyetlerinin neticesine rastlamaktadır. ${ }^{14}$

İran Osmanlı rekabetinin hanlıklar üzerinde etkin olma mücadelesinin devam ettiği bir sırada, İran Azerbaycan'daki hanlıkları tazyik ederken, Osmanlı devleti de buradaki hanlıkları yanına çekiyor ve onlara "yurtluk" ve "ocaklık" vererek, kendisine bağlamaya çalışıyordu. ${ }^{15}$ Örneğin 1731 yılında Gence Muhafızı İbrahim Paşa ve Revan Bölgesi Seraskeri olan Vezir Ali Paşa birlikte İran'a karşı hareket ederek, Osmanlı Devleti'ne hizmet etmelerine karşılık kendilerine "yurtluk" ve "ocaklık" verilerek, taltif edilmiş ve onlarla işbirliği yapılmıştır.

\footnotetext{
12 İsmail Özçelik, Devlet-i Aliye'nin Taşra Yönetimi, Gazi Kitabevi, Ankara, 2016, s.16.

${ }^{13}$ İsmail Özçelik, Devlet-i Aliye'nin Kamusal Düzeni ve Kurumları, Gazi Kitabevi, Ankara, 2014, s.202.

${ }^{14}$ Özçelik, Karabağ Tarihi ve Karabağ'da Ermeni Olayları, s.59.

${ }^{15}$ Osmanlı Devleti İle Azerbaycan Türk Hanlıkları Arasındaki Münasebetlere Dair Arşiv Belgeleri, (Karabağ-Şuşa, Nahçivan, Bakü, Gence, Sirvan, Seki, Revan, Kuba, Hoy), I, (1578-1914), Ankara - 1992, (BOA. Nâme-i Hümâyûn Defteri, nr. 7, s. 237-239), s. 7273.
}

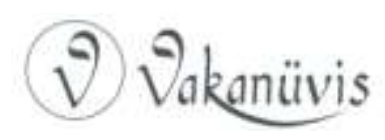


Bu yıllarda, İran hükümdarı Nadir Şah, (1736-1747) Karabağ'da meskûn olan ve İran'a boyun eğmeyen Cevanşir aşiretini Horasan Eyaleti'nin Serhas bölgesine sürmüştür. Fakat daha sonraları, aşiretin reisi Penah Ali Bey, bir şekilde firar ederek, Karabağ dağlarına çekilmiş ve İran'a karşı mücadele etmeye başlamıştır. Nadir Şah'ın öldürülmesinden sonra, Penah Ali Bey'in oğlu ibrahim Halil, Cevanşir aşiretini Horasan'dan Karabağ'a getirmeye muvaffak olmuştur. Cevanşir aşireti, Penah Ali Bey etrafında toplanarak, O’nun bağımsız bir hanlık kurmasında önemli bir rol oynamıştır. ${ }^{16}$

Bu gelişmelerin ardından 1750 yılında "Penah Han" adıyla Karabağ Hanlığı tahtına oturan Penah Ali Han, ${ }^{17}$ komşusu olan rakip hanlar ve İran'dan gelebilecek muhtemel taarruzlara karşı kendisini korumak ve savunmak amacıyla, müstahkem bir kale inşasını uygun görmüştür. Bu cümleden olmak üzere 1757 yılında Şuşa Kalesi'ni inşa ettirmiştir. ${ }^{18}$ Ele geçirilmesi bir hayli güç olan Şuşa Kalesi, İran saldırılarına karşı başarılı bir şekilde kullanılmıştır. Penah Ali Han'ın ismine izafeten bu kaleye "Penahabad" adı da verilmiştir. Zaman içinde burası Karabağ Hanlığının merkezi olmuştur. ${ }^{19}$

Daha sonra Penah Ali Han, kendi adına sikke kestirmiştir. Şuşa ve Han'ın adından ötürü bu sikkelere "Penahabadî" adı verilmiştir. ${ }^{20} \mathrm{Bu}$ durum, hanlığının bağımsızlığı ve Penah Ali Han'ın hükümdarlığının bir sembolü olmuştur. Nitekim bir rivayete göre de, Nuha Hanı (Şeki Hanı) Hacı Çelebi'nin Karabağ'ı ele geçirmek iddiası üzerine Penah Ali, kendi hısım akrabalarından ve Kürtlerden müteşekkil büyük bir kuvvetle Nuha yada Şeki Hanı Hacı Çelebi Han üzerine yürümüş ve onu mağlup etmiştir. Nuha Hanı Hacı Çelebi Han, Mağlup olduktan sonra Kür

\footnotetext{
${ }^{16}$ Bala, a.g.m., s.214.

17 Penah Ali Han'ın, Hanlığının meşruiyetini ispatlamak için, onun Hülagü Han'ın torunlarından Argun Şah'ın neslinden olduğu iddia edilmektedir ki, bu rivayet onun, hanlığı tesisinde rol oynayan önemli etkenlerden biridir.

18 Mirza Cevanşir Karabağlı, Karabağ Tarihi, (Çev. Tahir Sümbül), Kök Sosyal ve Stratejik Araştırmalar Serisi: 4, Ankara, 1990, s. 9.

${ }^{19}$ Özçelik, Karabağ Tarihi ve Karabağ'da Ermeni Olayları, s.60.

20 Peneh Ali Hanın, Karabağ Hanlığını kurması araştırmalarda farklı tarihlerle anılmaktadır. Genel olarak 1747 ve 1750 yılları anılmaktadır. Kuvvetle muhtemeldir ki Hanlığın kuruluşu 1747 olmalıdır. Keza Şuşa Kalesi'nin inşası da 1752 ve 1757 olarak farklı iki tarih söz konusudur.1747 tarihi hanlığın kuruluş tarihi olarak alınırsa inşasına ilişkin 1752 tarihinin doğru olması kuvvetle muhtemeldir.
}

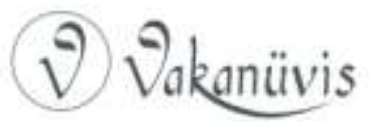


Nehri'nin öteki yakasına çekilmek zorunda kaldığında şunları söylemiştir: "Penah Ali, kendisini han ilan etmişti, ben ise mağlubiyetimle onun hanlığını tasdik etmiş oldum." Yine Hacı Çelebi Han'a isnat edilen bu rivayetin bir başka versiyonu da şu şekildedir: "Penah Ali bu zamana kadar sikkesiz bir gümüştü, biz geldik ona altın sikke verdik ve döndük." ${ }^{21}$

İran hükümdarı Nadir Şah'ın ölümünden sonra, onun komutanlarından ve Afşar Türklerinden olan Urmiyeli Feth Ali Han Afşar, devlet kurmak iddiasıyla İran'ın Urmiye şehrinde başkaldırarak Azerbaycan'ı fethetmek istemiştir. Bu amacını tahakkuk ettirmek için Urmiyeli Feth Ali Han Afşar, güçlü konumda olan Penah Ali Han'a elçiler ve değerli hediyeler göndererek, onu kendisine itaate ve ittifak yapmaya davet etmiştir. Ancak Penah Ali Han, böyle bir komutana itaat etmeyi, gururuna yedirememiş ve bu teklifi kendisi için utanç verici kabul ederek, elçilerin getirdiği bu talebi ret edip onları geri göndermiştir. Bu olay üzerine Feth Ali Han Azerbaycan, Urmiye ve diğer vilayetlerden büyük bir ordu toplayıp, Karabağ'ı ele geçirmek ve Penah Ali Han'ı ortadan kaldırmak amacıyla Şuşa Kalesi'ni kuşatmıştır. Ancak bu girişimi olumlu sonuçlanmamıştır. Bu nedenle Feth Ali Han, başarı elde edemeyince, ordusunun mağlup olması ve ayrıca kış mevsiminin yaklaşması üzerine Penah Ali Han'a barış teklif etmek zorunda kalmıştır. Penah Ali Han'a elçi göndererek şu teklifte bulunmuştur: "Eğer Penah Ali Han ordumdan aldığı esirleri geri verirse, benimle ittifak ve dostluk kurarsa, kızımı onun büyük oğlu Ibrahim Halil Ağa'ya vereceğim. Böylelikle de biz, ebedî akraba ve dost olacağız. Bir şartla ki, İbrahim Halil Ağa'yı benim yanıma göndersin. $O$, düğün töreni yapıldıktan, şirin içilip, kurban kesildikten ve 2-3 gün burada kaldıktan sonra geri dönsün."

Penah Ali Han, Feth Ali Han'ın bu teklifine ve barış isteğine inanarak ve kazandığı zaferin verdiği güven hissiyle oğlu ibrahim Halil'i bazı kethüdalarla birlikte Feth Ali Han'ın karargâhına göndermiştir. Ancak İbrahim Halil, bu hilekâr ve siyasî oyun sonucu Feth Ali Han tarafından esir edilmiştir.

\footnotetext{
${ }^{21}$ Ahmet-Bey Cevanşir, Karabağ Hanlığının Tarihi, (Haz. Yusuf Gedikli), Selenga Yay., İstanbul, 1993, s. 27-55.
}

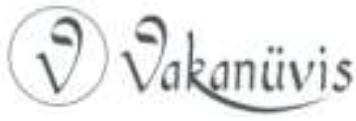


Bu sırada, İran ve Irak topraklarında devlet kurmuş olan Kerim Han Zend, müstakil hale gelmiş ve Feth Ali Han ile mücadeleye başlamıştır. Akrabalarından birini (muhtemelen kardeşi) serdar tayin ederek Feth Ali ile muharebeye görevlendirmiş ve ordusunu Azerbaycan'a göndermiştir. İsfahan taraflarında yapılan savaşı Feth Ali Han kazanmış ve Iran'da bir kısım yerleri alarak geri dönmüştür.

Bu olaydan sonra Kerim Han Zend, intikam almak isteğiyle Karabağ Hanı Penah Ali Han'a ittifak teklifinde bulunmuş, Penah Ali de hilekâr düşmanı olan Feth Ali'yi ortadan kaldırmak için bu teklifi kabul etmiştir. Íki müttefik Urmiye vilayetine doğru sefere çıkmışlardır. Müttefikler ordusu başarılı bir savaş sonucunda Feth Ali Han ve kuvvetlerini mağlup etmiştir. Kerim Han Zend, Feth Ali'ye ait Urmiye Kalesi'ni ele geçirmiş ve orada daha önce hile ile esir alınmış olan ibrahim Halil'i kurtararak ona at, kılıç, hilat vermiş ve kendisine ayrıca Karabağ Hanlığı hâkimiyeti fermanını sunmuştur. Ardından da onu törenle babasının yanına Karabağ'a yollamıştır.

İbrahim Halil'in Karabağ'a gelmesinden sonra, yöre ve civar vilayetlerin halkı da ona itaat etmiştir. Bu gelişmeler üzerine Penah Ali Han, hanlığı oğluna bırakarak, Kerim Han Zend'in payitahtı Şiraz'a gitmiş ve kısa bir süre sonra da ölmüştür. ${ }^{22}$ Böylece Karabağ Hanlığı tahtına İbrahim Halil Han oturmuştur.

\section{Karabağ Hanı İbrahim Halil Han'ın Rus Yayılmacılığı ve İran Baskılarına Karşı Osmanlı Devleti ile ílişkileri}

İbrahim Halil Han, cesur ve ihtiyatlı bir hükümdardı. İlmi, sanatı ve edebiyatı seven ve himaye eden bir kişiliğe sahipti. Han olunca sarayına devrinin âlim, şair ve sanatkârlarını toplamaya çalışmıştır. Azerbaycan Edebiyatının önde gelen isimlerinden biri olan şair Molla Penah Vakıf'ı vezirliğe getirmiştir. Azerbaycan'ın Sünni Türklerle meskûn Kazak eyaletinden olan Molla Penah Vakıf, İran'a kültür ve siyaset alanlarında karşı koymuştur. Karabağ Hanlığının tek başına kendini müdafaa edemeyeceğini düşünen bu ileri görüşlü vezir, komşu Türk hanlıklarıyla ittifaklar kurmayı başardığı gibi, Osmanlı Devleti'ne de bir elçi göndermiş ve ilişkilerini sağlamlaştırmak istemiştir. Bütün bu

${ }^{22}$ Karabağlı, a.g.e., s. 10-12.

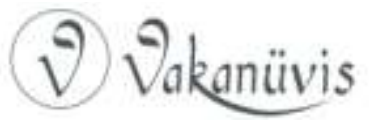


tedbirler o yıllarda Karabağ Hanlığınım İran'a boyun eğmeyeceğinin işareti sayılmalıdır. ${ }^{23}$

1775 yılına gelindiğinde Dağıstan Hanları ile Osmanlı Devleti'nin dikkatini çeken husus, Tiflis'teki Gürcistan Hanı Irakli Han'ın Rusya ile olan yakınlaşmasıdır. Her iki taraf da bu yakınlaşmayı istememekte ve Gürcistan Hanı Irakli Han'ı Rusya'dan bir şekilde uzak tutmaya çalışmışlardır. ${ }^{24}$ Nitekim 1776 yılında Çıldır Beylerbeyine yazılan bir arzuhalde, Sarı Mustafa Paşa Kalesi'nin, Gürcistan Hanı Irakli Han'ın Ruslara tabiiyeti sonucunda Rus askerlerinin kuşatması altında olduğu ve civar köylerin yakılıp yıkıldığından bahsedilmektedir. Yine aynı belgede, Muhammed Hasan Han'ın yardıma gelmesi üzerine Rusların geri çekildiği, yardım edilirse, Rusların bir şey yapamayacağı ve Müslümanların el ele verip birbirlerine yardım etmeleri gerektiği kayıtlıdır. ${ }^{25}$

Karabağ Hanı İbrahim Halil Han'ın yıllarca Derbent Hanı Feth Ali Han ve Şirvan ve Şeki Hanı Hüseyin Han ile aralarında şiddetli anlaşmazlık ve husumet söz konusuydu. Hatta İbrahim Han bu sırada Şeki Hanı olan Hüseyin Hanın oğlunu bir şekilde ele geçirip hapis etmiş ve bunanla da yetinmeyerek, Karadağ ve Bakü Hanlarını da esir almıştır. Bu gelişmeler üzerine Feth Ali Han, Hüseyin Han ile birlikte asker toplayarak Karabağ Hanı İbrahim Han'ın üzerine gelmek üzere harekete geçmişlerdir. Ancak çıkan anlaşmazlık üzerine Hüseyin Han amcası tarafından öldürülünce, İbrahim Halil han bu tertipten kurtulmuştur. Kendine güveni artan İbrahim Han hedeflerini büyüterek Tebriz'i dahi ele geçirebileceğini düşünmeye başlamıştır. İbrahim Halil Han bu arzusunu gerçekleştirmek için Tebriz'e kayın biraderi Nazar Ali Hanı çok sayıda

\footnotetext{
${ }^{23}$ Bala, a.g.m., s. 215.

${ }^{24}$ Cemal Gökçe, Kafkasya ve Osmanlı Imparatorluğunun Kafkasya Siyaseti, İstanbul, 1979, s. 108.

25 "Pes lâyık-ı İslâmiyân oldur ki el ele verüb dindarlıkda birbirine hamiyyet edüb yardım kılalar ve bir dahi arzımız oldur ki, her gâh lüft edüb sâyir havânînlerden su'âl olunur ise devletlü Şeki Hanı Şirvan ve Karabağ serkerdelerin ki Alicanlı Mehmed Sa'id Han ve İbrahim Han ve ağası han ve andan gayrılarında tamamen sözlerin bir kılub ki eğer İslâmiyân tarafına şol kâfirden asker gele ve hâdise yüz vere umûmen i'anet ederler..." Osmanlı Devleti ile Azerbaycan Türk Hanlıkları Arasındaki Münasebetlere Dâir Arşiv Belgeleri, (Karabağ-Şuşa, Nahçivan, Bakü, Gence, Sirvan, Seki, Revan, Kuba, Hoy), I, (1578-1914), Ankara - 1992, (BOA, Hatt-ı Hümayûn, nr. 94-G), s. 61.
}

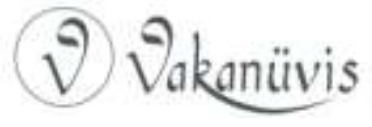


askerle göndererek saldırmış, ahali kalede mahsur kalmıştır. Ancak Tebriz Hanı Necefkulu Han da bu saldırıdan kaçarak Hoy Hanı Ahmet Han'a sığınmak zorunda kalmıştır. ${ }^{26}$

Tebriz Hanı Necefkulu ve Hoy Hanı Ahmet Han arabuluculuk yapması için Gürcü Tiflis Hanı Öke Han'a başvurmuşlar ve Öke Han bunun üzerini hatırlı bir adamını Karabağ Hanı İbrahim Han'a göndermiştir. ${ }^{27} \mathrm{Bu}$ geliş̧melerden sonra Osmanlı Padişahı I. Abdülhamid'in bir Hattı Hümayunu Çıldır Valisi Vezir Süleyman Paşa'ya göndererek izlenecek yol hakkında direktifler verdiği görülmektedir. ${ }^{28}$

İbrahim Halil Han'ın saltanatı, Rusya'nın toparlanıp Kafkasya'ya doğru yayılmaya başladığı ve İran'da da taht kavgalarının şiddetlendiği bir zamana rastlamaktadır. İbrahim Halil Han, 1783 yılında ilk iş olarak Gürcistan'ı ilhak eden Rusya'nın tahrikiyle başta Arran Katagikos'u olmak üzere, Karabă̆'ın Ermeni beyleri tarafından çıkarılan bir isyanı bastırmıştır.(1783)Ardından aynı yıl Ruslarla birlikte hareket eden Tiflis Hanı Azerbaycan hanlarının işbirliği sayesinde yenilgiye uğratılmıştır. Karabağ Hanı İbrahim Halil Han ile diğer Azerbaycan hanlarına Osmanlı Devleti'nce gönderilen hediye ve emr-i şerif dolayısıyla memnuniyet duymuş ve Osmanlı Devleti'ne sadakatlerini bildirmişlerdir. Ardından yaşanan gelişmeler sonucunda, Tiflis Hanı Rus askerleriyle birlikte Dağıstan ve Azerbaycan'daki hanlıklara karşı yürüttüğü savaşlar sırasında Rus generalinin öldüğü ve hanın da askerleriyle çekildiği Çıldır Beylerbeyi Süleyman Paşa'dan alınan bir tahrirattan anlaşılmaktadır. Çıldır Beylerbeyi Süleyman Paşa'dan alınan yazı üzerine Padişah, Hanların Osmanlı Devleti'ne dostluk ve bağlılıklarını isteyen bir hatt-ı hümayun hazırlatmıştır. ${ }^{29}$

Ancak bundan birkaç yıl sonra durum değişecektir. Nitekim 1790 yılındaki bir hatt-ı hümayunda, davet olunduğu bütün seferlerde

\footnotetext{
${ }^{26}$ Bkz. BOA, Hattı Hümayun, No:6, (Tarih: 27 Şevval 1194/ 26 Ekim 1780), s.1. Osmanlı Istihbarat elemanlarının verdikleri bilgiler çerçevesinde düzenlenmiş ve Padişaha arz edilmiş olan Hattı Hümayun.

${ }^{27}$ BOA, Hattı Hümayun, No:6, (Tarih: 27 Şevval 1194/ 26 Ekim 1780), s.1.

${ }^{28}$ Bkz. BOA, Hattı Hümayun, No: 11/377 (Tarih:1200/1785), s.1.

${ }^{29}$ Osmanlı Devleti Ille Azerbaycan Türk Hanlıkları Arasındaki Münasebetlere Dair Arşiv Belgeleri, (Karabağ-Şuşa, Nahçivan, Bakü, Gence, Sirvan, Seki, Revan, Kuba, Hoy), I, (1578-1914), Ankara - 1992, (BOA. Cevdet Dâhiliye, nr. 15122), s.101-102.
}

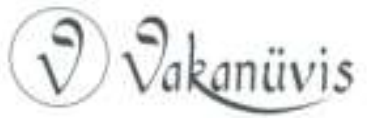


Osmanlı ordusu yanında Dağıstan askeriyle birlikte Tiflis Hanı ve Ruslara karşı başarılı mücadelelerde bulunan Şuşa ve Karabağ Hanı Ibrahim Han'ın, Osmanlı Devleti'nin kendisine asker gönderememesinden dolayı bölgede gerekli etkinliğinin kurulamadığı ve bazı hanların Ruslara tabi olduğu anlaşılmaktadır. Ruslara karşı savaşmak isteyen Ibrahim Halil Han, Osmanlı Devleti'nden yardım talebinde bulunmuştur. Kendisine yardım edilmezse durumun Osmanlı Devleti aleyhine gelişeceği ifade edilmiştir. Bununla beraber Rusya ile ittifak kuran Tiflis'teki Gürcistan Hanı İrakli Han da Osmanlı Devleti ile dost olmak istemiştir. ${ }^{30}$

Bu arada İran'da bir kısım hanlıkları kendine bağlayan Esterâbâd Hanı Ağa Muhammed Han'a tabi olmayan Revan, Şuşa, Gence, Tiflis, Dağıstan ve Şirvan hanlıkları aralarında ittifak kurulmuştur. Muhammed Han da bu ittifakı yıkmak için, müttefik hanlara karşı saldırı hazırlığı yapmıştır. Mezkûr Han'ın Revan'a saldırması durumunda Kars, Bayezid, Erzurum, Van ve civarının büyük zarar göreceği ve halkın böyle bir saldırı karşısında göçe mecbur kalırsa, önceden olduğu gibi Osmanlı sınırları içinde himaye olunması hususunda Halil ibrahim Han, Osmanlı payitahtına başvurmuştur. Bu minval üzere, Padişah I. Abdülhamid döneminde Revan'ın Osmanlı mülkü olduğunu hatırlatan Revan Hanı Muhammed Han da Osmanlı Devleti'nden yardım istemiş ve Karabağ, Gürcistan vesaire Azerbaycan memleketlerinden gelecek mültecilerin kabulü için gerekli önlemlerin alınması ricasında bulunmuştur.

Tahran'dan hareketinden itibaren Ağa Muhammed $\mathrm{Han}^{\prime 31}$ ın durumundan haber almak için gönderilen casusların verdiği malumata

\footnotetext{
${ }^{30}$ Osmanlı Devleti İle Azerbaycan Türk Hanlıkları Arasındaki Münasebetlere Dair Arşiv Belgeleri, (Karabağ-Şuşa, Nahçivan, Bakü, Gence, Sirvan, Seki, Revan, Kuba, Hoy), I, (1578-1914), Ankara - 1992, (BOA, Hatt-ı Hümayûn, nr. 57046), s.132.

${ }^{31}$ Ağa Muhammed Han Kaçar, Kaçar Aşireti'nin reisi (1742-1794), 1794-1925 yılları arasında İran'a hakim olan Kaçar Hanedanı'nın kurucusudur. 1794-1797 yılları arası İran Şahı olarak hüküm sürmüştür. Adil Şah emirleri ile öldürülen babasi Muhammed Hasan Han yerine Kaçar aşiretinin reisi olmuştur. 1794'de İran Şahları olan Zend Hanedanı 'nın mensupları arasında İran Şahliği için çıkan saltanat kavgasından faydalanarak kendini İran Şahı ilan etmiş ve 1794-1925 yılları arasında Şah olarak hakimiyet sürüp, Kaçar Hanedanı'nın kurucusu olmuştur. 1797'de yerine İran Şahı olarak yeğeni Feth Ali Şah Kaçar geçmiştir.
}

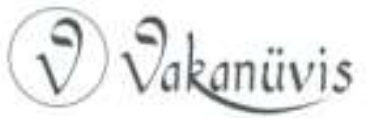


göre, Şuşa ve Karabağ civarındaki köyler tahrip edilmiştir. Ağa Muhammed Han, daha sonra Tiflis'e hücum etmiştir. Gürcistan Tiflis Hanı karşı koyamayıp kaçmış ve nereye gittiği bilinememiştir. Osmanlı Devleti, hudut halkına zarar vermemesi için uygun bir görevlinin hediyelerle mahalline gönderilerek durumunun tahkik edilmesinin faydalı olacağını düşünüp bu yönde girişimde bulunmuştur. ${ }^{32}$ Ancak sonraki gelişmelerden anlaşılıyor ki, Gürcistan Tiflis Hanı İrakli Han, Şuşa ve Karabağ Hanı İbrahim Halil ile birlikte bir ittifak kurmuştur. Nitekim bu iki han büyük bir kuvvetle Gence'ye hücum etmişlerdir. Mevcut yazışma ve kayıtlardan anlaşıldığına göre, Osmanlı Devleti'nin yine bölgede ve hanlıkları kendisine bağlamada bu yıllarda pek başarılı olamadığı ve elçiliklerle hediye göndermek suretiyle pasif bazı girişimlerle ilişkilerin geçiştirildiği anlaşılmaktadır.

Aslında Revan Hanlığı ve diğer bazı hanlıklar 1795 yılında Osmanlı toprağıydı. Sultan I. Abdülhamid devrinde Revan'ın Devlet-i Aliye mülkünden olduğu ve İran tarafından gelen saldırılara karşı yardım talebinde bulunan Revan Hanı Muhammed Han'ın yazılı isteğinden anlaşılmaktadır. Burası ile beraber Karabağ, Gürcistan vesaire Azerbaycan memleketlerinin muhafazasına yardım edilmesi ve hatta buralardan gelecek mültecilerin kabul edilmesi için gerekli tedbirlerin alınması çeşitli yazışmalarla istenmiştir. ${ }^{33}$

Karabağ Hanı İbrahim Halil Han'da bu yıllarda Osmanlı Devleti ile koordineli çalışmış ve Hanlıklar ile İran ve Rusya arasındaki ilişkiler neticesinde kendi aralarındaki münasebetleri Osmanlı Devleti ile yaptığı yazışmalarla gerekli tedbirler konusunda bilgilendirmeler yapmıştır. Mesela 9 Mayıs 1795 tarihinde gönderdiği bir yazıda Halil Ibrahim Han, İran'da birçok hanlıkları kendine bağlayan İran Şahı Ağa Muhammed Han'ın elde edemediği Revan, Şuşa, Gence, Tiflis, Dağistan ve Şirvan hanlarıyla Şemhal'in aralarında ittifak oluşturduklarını bildirmiştir. Bu yazıda Ağa Muhammed Han'ın mezkûr müttefik hanlara

\footnotetext{
${ }^{32}$ Osmanlı Devleti ile Azerbaycan Türk Hanlıkları Arasındaki Münâsebetlere Dâir Arşiv Belgeleri, (Karabağ-Şuşa, Nahçivan, Bakü, Gence, Sirvan, Seki, Revan, Kuba, Hoy), I, (1578-1914), Ankara - 1992, (BOA, Hatt-ı Hümayûn, nr. 6694), s.148.

${ }^{33}$ Osmanlı Devleti ille Azerbaycan Türk Hanlıkları Arasındaki Ünâsebetlere Dair Arşiv Belgeleri, (Karabağ-Şuşa, Nahçivan, Bakü, Gence, Sirvan, Seki, Revan, Kuba, Hoy), I, (1578-1914), Ankara - 1992, (BOA. Hatt-ı Hümâyûn, nr. 6748), s. 151-155.
}

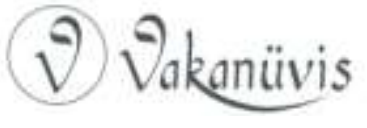


saldırı hazırlığı yaptığı ve Revan'a saldırması hâlinde ona sınır olan Kars, Bayezid, Erzurum, Van ve civarının büyük zarar göreceği ve halkın böyle bir saldırı karşısında göçe mecbur olacağını hatırlatmıştır. Buraların önceden olduğu gibi Osmanlı sınırları içinde himâye olunması ve Devlet-i Aliye'nin haklarında ne yönde irade buyurursa gereğinin aynen tatbik olunacağını söylemiştir. ${ }^{34}$

İran'ın Hanlıklar üzerindeki bu baskı ve tazyikleri sürerken, kuzeyden de 1796 yılından itibaren Rus baskı ve yayılmacılığı başlamıştır. Nitekim Azerbaycan'a Ruslar tarafından bölgeye asker sevki ve hanlıklara ait bu sahaların işgal edilmesine Türk Hanlıkları buna tepki göstermişlerdir. Bu bağlamda Bakü, Şirvan, Derbent ve diğer Türk hanlıkları birlikte hareket ederek Rus kuvvetlerini yenilgiye uğratıp, onları geri çekilmeye mecbur bırakmışlardır. ${ }^{35}$

Bu sırada Azerbaycan bölgesinde ve Kafkasya'da zaten öteden beri etkili olan İran, bölge üzerindeki etkisini sürdürmeye devam etmiştir. İzlediği politikalarıyla İran'a boyun eğmek istemeyen Karabağ Hanlığına karşı İran harekete geçmiştir. Rusya'nın himayesini kabulünden dolayı Gürcistan'ı cezalandırmak için sefere çıkan Ağa Muhammed Han Kaçar, 85.000 kişilik ordusuyla Karabağ'dan geçmiş, ancak burada Karabağ Hanlığı tarafından şiddetli bir mukavemetle karşılaşmıştır. Bu nedenle muhasara ettiği Karabağ Hanlığının merkezi olan Şuşa kalesini alamadan geri çekilmek zorunda kalmıştır. Ağa Muhammed Han'ın emriyle Nahcivan Hanı olan Kelp Ali Han da Karabağ'daki bir kısım

\footnotetext{
${ }^{34}$ Şuşa ve Karabağ Hanı Halil İbrahim Han'ın arizasını getiren Seyit Abdullah Çelebi ve Revan Eşik Ağası Hacı Zeynel Ağa olmuşlardır. Osmanlı Devleti İle Azerbaycan Türk Hanlıkları Arasındaki Münasebetlere Dair Arşiv Belgeleri, (Karabağ-Şuşa, Nahçivan, Bakü, Gence, Sirvan, Seki, Revan, Kuba, Hoy), I, (1578-1914), Ankara - 1992 (BOA. Hatt-ı H BOA. Hatt-ı Hümâyûn, nr. 6748-A), s.155-159.

${ }^{35}$ Hüseyin Baykara, Azerbaycan'da Yenileşme Hareketleri, Türk Kültürünü Araştırma Enstitüsü Yay., Ankara, 1966, s. 11.
}

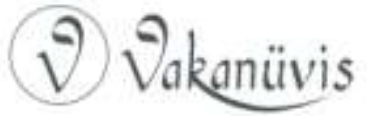


köyleri yağmalamıştır. ${ }^{36} 1796$ yılında yaşanan bu olaylar Azerbaycan edebiyatına da yansımıştır. ${ }^{37}$

Karabağ Hanlığı'nın merkezi olan Şuşa şehrine daha sonra girmeyi başaran Ağa Muhammed Han Kaçar, buradaki şehir halkını katletmiştir. Bu esnada, Muhammed Han'ın Şuşa'yı ilk kuşatmasında, şehrin teslimi için yazmış olduğu davet metnindeki beyte aynı tarzda cevap veren şair ve Karabağ Hanlığı veziri Molla Penah Vakıf, esir alınmış ve ölüme mahkûm edilmiştir. Fakat Muhammed Han'ın 18 Nisan 1797 gecesi üç hizmetkârı tarafından öldürülmesi sonucunda Karabağ Hanlığı veziri Molla Penah Vakıf bu mahkûmiyet ve cezadan kurtulmuştur. Vezir Vakıf, bu olayı dostu olan şair Vedâdî'ye manzum olarak hikâye etmiştir.

İran'da şahlık iddiasında bulunan Ağa Muhammed Han 1797 yılında Karabağ Hanlığı'na ikinci bir sefer düzenlemiştir. Bu sefer sırasında Karabağ Hanlığı siyasi bakımdan çok uygun olmayan şartlar içinde bulunuyordu. Zira müttefiki olan bazı Türk hanlıkları, İran hâkimiyetine girmek zorunda kalmış ve İran ordusunun üst üste yaptığı hücumlara uzun süre direnen İbrahim Halil Han, Osmanlı Devleti'nden de hiçbir yardım alamamıştı. İbrahim Halil Han, açıı ve kıtlık dolayısıyla halkın direncinin azalmaya başladığını görünce, Ağa Muhammed Han'ın baskıları neticesinde Şuşa Kalesi'ni terk etmiş ve Kafkasya dağlarının eteğindeki Ilısu Hanlığı'na çekilmiştir.

Bu gelişmeler sonucunda, Karabağ Hanı İbrahim Halil Han, kızını İran'da şahlık iddiasında bulunan Ağa Muhammed Han'ın birader zadesi Baba Han Serdarına vermiştir. Bu arada Gürcü Tiflis Hanı İraklı Han'ın hastalığı münasebetiyle yerine oğlu Gorgi geçmiş, ancak bu gelişme diğer kardeşler arasında bir dizi anlaşmazlık ve huzursuzluğa sebep olmuştur. Bu sırada Tiflis Hanlığının Osmanlı Devleti'ne tabi olma temayülleri de zuhur etmiş, ancak Gürcistan hanları ve prensleri

\footnotetext{
36 “... Ağa Muhammed Han’ın emriyle Hançıvan Hanı Kelp Ali Han külliyetlü süvârî asâkir ile bâ-ılgâr Şuşa hânının zîr-i hükmünde olan Karabağ kurasını nehb ü gayret eyleyip..." Osmanlı Devleti İle Azerbaycan Türk Hanlıkları Arasındaki Münâsebetlere Dâir Arşiv Belgeleri, (Karabağ-Şuşa, Nahçivan, Bakü, Gence, Sirvan, Seki, Revan, Kuba, Hoy), I, (1578-1914), Ankara - 1992, (BOA, Hatt-ı Hümâyûn, nr. 7093), s.155.

${ }^{37}$ Baykara, a.g.e., s. 79.
}

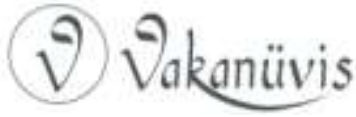


Rusya'ya bağlı olmakla birlikte zaman zaman iç anlaşmazlıklar sebebiyle Osmanlı Devleti'ne meyletmişlerdir. ${ }^{38}$

Osmanlı devlet adamları onların bu isteklerinin geçici olduğuna ve samimi olmadıklarına inandıklarından bu taleplerine fazla ehemmiyet vermemişlerdir. $^{39}$ Hanlıkların birbirleriyle, İran ve Rusya ile mücadelelerinde ibrahim Halil Han her zaman Osmanlı Devleti'nin yanında yer almış ve Osmanlı payitahtına bağı kalmıştır. Öyle ki, bulunduğu bölgede Osmanlı́nın bir memuru gibi vazife görmüştür. Onun bu tutumu Osmanlı yazışmalarında hep takdirle anılmıştır. ${ }^{40}$

\section{Karabağ Hanlığının Rus İdaresine Bağlanması}

Çarlık Rusya'sı XIX. asrın başlarından itibaren bütün Kafkasya'da kararlı bir yayılma ve baskı politikası izlemiştir. Bu bağlamda Rusya, bölgede bulunan hanlıkları kendi tarafına çekmek ve himayesi altına almak için çeşitli teşebbüslerde bulunmuştur. Illk önce 1801'de

38 “...Tiflis Hanı İrakli Han müddet-i vâfireden berü Kâhıt nâm mahalde hasta ve sâhib-i fîrâş olub hayâtından me'yûs olduğundan oğullarından Görgi nâmında kebîr oğlunu Tiflis'e hân nasb eylediğinden diğer oğulları babalarının bu tedbîrine razı olmadıklarından nâşî eyâlet-i muhlisîye kurb u civar oldukları hasebiyle Devlet-i Aliyye-i dâimü'l-karâra arz-ı ubûdiyyet ve sıdk u istikâmet suretleri rû-nümâ olarak ve fi-mâba'd Rusyalu'dan ferd-i vâhid Tiflis ve havâlîsine duhûl etdirmemek hâletlerini ta'ahhüd ve niyâz eylemeleriyle bu hılâlde hân-ı mersûmu sarsar-ı bâd-ı ecel hayât-ı çirk-âlûdunu resîde-i dereke-i bi'se'l-masîr etmekle oğulları hânlık iddi'âsıyla birbileriyle mu'âraza ve münâza'aya derkâr olacakları bedîdâr olmakla Devlet-i Aliyye-i ebediyyü'l-karâra ilticâ ve hulûs-kârlarına istimdâd için oğullarından birisi nezd-i muhlisîye vürûd eylediği hâlde ta'ahhüd ve niyâzlarına milel-i âhar olduğundan ve cânib-i ihlâskârlarına i'timâd-ı kavî hâsıl olmadığından iktizâ eden cevâbı irâde-i Devleti Aliyye'ye menût ve muhtâc olduğundan keyfıyyet-i mezbûre bir kıt'a arzuhâl-i ubeydânemiz ile hâk-i pây-ı hazret-i veliyyü'l-ni'amîye arz u takdîm olunmağla..." Osmanlı Devleti ille Azerbaycan Türk Hanlıkları Arasındaki Münâsebetlere Dâir Arşiv Belgeleri, (Karabağ-Şuşa, Nahçivan, Bakü, Gence, Sirvan, Seki, Revan, Kuba, Hoy), I, (1578-1914), Ankara - 1992, (BOA, Hatt-ı Hümâyûn, nr. 1700-A), s.160.

${ }^{39}$ Gökçe, a.g.e., s. 186.

40 “...ibrahim Halil Han yirmi beş seneden mütecaviz Devlet-i Aliyye'ye arîza takdimi ile izhâr-ı bendegî ve rıkkıyyet eylediğinden başka taraf-ı Devlet-i Aliyye'den dahi bi'ddefe'ât evâmir-i aliyye irsâliyle mazhar-ı iltifat buyurulmuş olduğuna bina'en hân-ı mûmâ-ileyh leyl ü nehâr devâm-ı devlet-i şâhâne ve kıyâm-ı fer u haşmet-i pâdişâhâne ed'ıyesiyle evkât-güzâr ve sıdk u ihtisası ez-dil ü cân iltizâma ibtidar etmeğle..." Osmanlı Devleti ile Azerbaycan Türk Hanlıkları Arasındaki Münâsebetlere Dâir Arşiv Belgeleri, (Karabağ-Şuşa, Nahçivan, Bakü, Gence, Sirvan, Seki, Revan, Kuba, Hoy), I, (1578-1914), Ankara - 1992, (BOA, Hatt-ı Hümâyûn, nr. 6748-A), s.143.

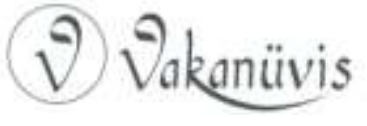


Gürcistan'ı ele geçiren Ruslar, buradan doğuya ve güneye doğru Azerbaycan'ın esas hanlıklarına karşı askeri kuvvetler sevk etmişlerdir. Ruslar Trans Kafkasya'daki hanlıkların fethi için oluşturdukları çok sayıdaki askeri birliğin başına başkomutan sıfatıyla Prens Sisianov'u getirmişlerdir. Sisianov, işe 1803 yılında Gence Hanlığını işgalle başlamış ve 2 Ocak 1804 tarihinde bu hanlığın merkezi olan Gence şehrini ele geçirmiştir. Ardından Prens Sisianov Gence Hanlığının adını değiştirerek, buraya Rus Çariçesi Elizabeth'in onuruna, "Elizabethol" adını vermiştir. ${ }^{41}$

Rusların Kafkaslardaki bu ilerleyişi Osmanlı Devleti ile İran Şahlığını endişeye sevk etmiştir. Diğer taraftan Rusların Kafkasların güneyine doğru inmeleri, İngiltere ve Fransa'nın da hoşuna gitmemiştir. İngiltere ve Fransa Rusların Güney Kafkasya'dan atılması için Osmanlı Devleti ve İran'ı Ruslara karşı tahrik etmeye başladılar. Bu tahriklere karşı İran şahlığı geri adım atmamıştır. Tam aksine Şah Rusya'yı Kafkasların kuzeyine atmak maksadıyla 1804'te Ruslara savaş ilan etmiştir. Rusİran savaşında şahlığın Karabağ topraklarını istila edeceğinden endişelen Karabağ Hanı İbrahim Halil Han, bu sırada prens Sisianov'a müracaat ederek, kendisinden yardım istemiştir. Bunun karşılığında da Rusya'ya sadık kalacağını bildirmiştir. Rus Generali Sisianov ise Rusya'nın hâkimiyetini kabul etmesi durumunda onu Han gibi tanıyacağını vaat etmiştir.

İbrahim Halil Han, kendisini ikna etmeye dönük vatlara ve baskılara rağmen mütereddit kalmıştır. Eğer Rusya'dan yardım istemezse İran Şahlığı tarafından Karabağ Hanlık topraklarının ele geçirilmesi gerçekleşecekti, İbrahim Halil Han, bu zor durumda Rusları daha ehven-i şer görmüş ve böylece sonunda Ruslara yakın bir siyaset izlemeye başlamıştır.

Bu sırada, İran Şahı Karabağ’a kuvvet gönderdiyse de İbrahim Halil Han, bu askeri kuvveti mağlup etmiştir. Hanın İran ordusunu yenmesiyle şahın bütün dikkatini üzerine çekeceği ihtimal ve endişesinden hareketle çeşitli arayışlara girişti. Bu esnada siyasî bir

\footnotetext{
${ }^{41}$ Ruslar Gence' ye öyle baskı yaptılar ki, Azerbaycan tarihçilerinden Mahmut İsmail'in ifadesiyle belirtmek gerekirse: "Kimi şehri Gence adıyla çağırsaydı, bir manat cerime edilirdi." Derken, şehrin asırlar boyu Türkçe ifade olunan isminin söylenmesi dahi cezayı ödemek için yeterli sebep sayılmaktaydı.
}

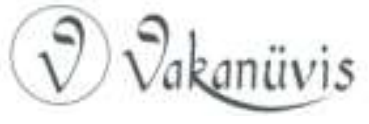


yalnızlık içinde kaldığını gören İbrahim Halil Han, başka çıkış yolu bulamadığından Rus Generali Sisianov ile görüşmelere yeniden başlamıştır. 14 Mayıs 1805 tarihinde İbrahim Halil Han ile Sisianov arasında Karabağ Hanlığı'nın Rusya'nın hâkimiyetini kabul etmesi yolunda bir anlaşma imzalanmıştır. ${ }^{42}$

Küre Çayı sahilinde yapılan bu anlaşmada Karabağ Hanı'nın yanı sıra Şeki Hanı Selim Han da hazır bulunmuştur. Şeki Hanlığı dış tehlikelerden -şimdilik kaydıyla- uzak kalmış, ancak içişleri bir hayli karışmıştır. Karabağ Hanı ỉbrahim Halil Han'ın ardından Bir hafta sonra, Şeki Hanlığı da Rusya'nın himayesini kabul etmiştir. Karabağ ve Şeki Hanlıkları yapılan anlaşmaya göre, her yıl Rus çarına 7.000-8.000 Manat verecek, Rus askeri kuvvetleri hanlıklarda istihdam edilecek, hanlıklar içişlerinde serbest, dışişlerinde ise Rusya'ya bağıı olacaklardı. Böylece Karabağ Hanlığı Rusya'ya bağlanmıştır.

Karabağ ve Şeki Hanlıklarının Rusya'ya bağlanmasından bir ay sonra İran kuvvetleri Karabağ'a saldırmışlardır. Bu durum İran ile Rusya'nın arasını açmış ve savaşa sebep olmuştur. General Sisianov, Bakü Hanlığını ele geçirdiği sırada öldürülmüştür. Bu olaydan sonra Rusya, Kafkaslardan Bakü'ye doğru harekete geçmiştir. İran da Karabağ'a sokularak Şuşa kalesini kuşatmıştır. İbrahim Halil Han, İran'ın Şuşa'yı kuşatması üzerine ailesini Hankendi'ye götürmüştür. Rus Çarlığının askerî kuvvetleri, Han'ın bu hareketinden şüphelenmişlerdir. Bu nedenle ibrahim Halil Han'ı takibe alan Rus kuvvetleri, bir gece vakti Binbaşı Lisanevich komutasında Hankendi'ye gelmiş ve İbrahim Han'ı tüm ailesiyle birlikte öldürmüşlerdir.

Bu olay Şeki'de Ruslara karşı bir isyana sebep olmuştur. Şeki Han'ı, Rus kuvvetlerini Hanlığının arazisinden kovmuştur. Ancak bu hadiseler olduğu sırada Rus birlikleri Karabağ'a girmiş, İran kuvvetlerini geri çekilmek zorunda bırakmış, Bakü Hanlığı da dâhil olmak üzere Hanlıklar Rus idaresine bağlanmıştır. Şeki Hanı, Rus takibinden kurtulmak için İran'a sığınmıştır. Böylece Çarlık Rusya'sı 1803-1805 yılları arasında uyguladığı siyasî ve askeri faaliyetler sonucunda, Karabağ Hanlığını tamamen kendi topraklarına katmıştır.

${ }^{42}$ Özçelik, Karabağ Tarihi ve Karabağ'da Ermeni Olayları, s.71.

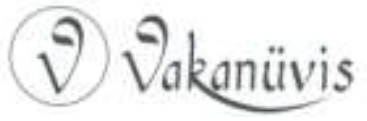


$\mathrm{Bu}$ gelişmelerden sonra Karabağ topraklarına Ruslar tarafından bilinçli ve planlı bir şekilde Ermeni göçü hızlandırılmış, Türkler azınlık durumuna düşürülerek Karabağ'daki bugünkü problemlerin hazırlanmasına zemin hazırlanmıştır. ${ }^{43}$

İbrahim Halil Han'ın öldürülmesi üzerine Karabağ Hanlığında yerine Mehdi Kulu Han geçmiştir. 1813 yılında imzalanan Gülistan anlaşmasından sonra, İran'ın Karabağ üzerindeki haklarından tamamen feragat ettiğini iddia eden Rusya, Karabağ topraklarına temelli olarak yerleşmeye başlamıştır. ${ }^{44}$ İran, 1826 yılında Rusya ile yapmış olduğu Gülistan anlaşmasını bozmuştur. İran Sefir sıfatıyla İran'da bulunan Rus Prens Menşikov'u geri göndermiş ve Rus devletine ait topraklara sokulmuştur. Bu arada Abbas Mirza komutasındaki İran ordusu, Şuşa Kalesi'ni kuşatmıştır. Rus kumandanı General Reutta askerinin azlığına ve mühimmatının olmamasına rağmen İran askerlerine karşı başarılı bir mukavemet göstermiş ve onları Şuşa'ya sokmamıştır. ${ }^{45}$

Rus İran mücadelesi, 1828 yılında İran ile Rusya arasında yapılan Türkmençay Anlaşması'yla son ermiştir. Azerbaycan toprakları Kuzey ve Güney Azerbaycan'ı bölen bir sınır ile çizilmiş ve iki ülke arasında paylaştırılmıştır. ${ }^{46}$ İran'ın mağlubiyeti ve 1828 tarihli Türkmençay Anlaşması'yla sonuçlanan bu harp esnasında Karabağ beylerinin Şuşa'yı muhasarası olumlu bir sonuç vermemiştir. Bu başarısından sonra, Kuzey Azerbaycan'a temelli olarak yerleşen Rusya, bir müddet hanlığın eski idari teşkilatını muhafaza etmişse de, az zaman sonra, bütün memleketi yeni bir idari taksimata tabi tutmuştur. Şuşa, Cevanşir, Cebrail ve Zengenzur kazalarına ayrılan Karabağ, bir aralık Gence, Şirvan, Şeki, Talış, Bakü, Küba ve Derbent Hanlıklarıyla birlikte kurulması düşünülen Müslüman Vilayeti içine alınmak istenmişse de 1868 yılına kadar Bakü Vilayeti dâhilinde bulunmuştur. Bu tarihte Gence Vilayeti teşekkül etmiş ve Karabağ bu vilayetin içinde yer almıştır. $^{47}$

\footnotetext{
${ }^{43}$ Zekeriya Türkmen, "Karabağ Hanlığının Rus İdaresine Bağlanması Meselesi”, Avrasya Etütleri, Ankara, 1996, c. III, S. I, s. 114-116.

${ }^{44}$ Bala, a.g.m., s. 215.

${ }^{45}$ Karabağlı, a.g.e., s. 31.

${ }^{46}$ Doğuştan Günümüze Büyük İslam Tarihi, Çağ Yay., Ek Cilt, İstanbul, 1986, s. 271.

${ }^{47}$ Bala, a.g.m., s. 215-216.
}

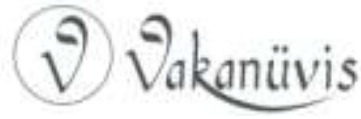


Bu gelişmelerden yıllar sonra, Çarlık Rusya'sında meydana gelen 1905 ihtilali $^{48}$ esnasında Ermeniler ile Azeri Türkleri arasında ilk ciddi ve kanlı çatışmalar başlamıştır. 1905-1907 yılları arasında devrim hareketi başladığında Çarlık, Güney Kafkasya'daki devrim taraftarları hareketi önlemek için Kafkasya'da karışıklığın devamını sağlamak maksadıyla Ermenilerin Türklere olan saldırılarını teşvik etmiştir. 6 Şubat $1905^{\prime}$ te Bakü'de başlayan katliam daha sonra Erivan, Nahçivan ve Şuşa şehirlerine sıçramıştır. 1905 yılı faciasının başlangıcı Bakü'de Şubat ayında yaşanan olaylar olmuştur.

Bakü'de Şubat ayındaki bu hadiselerde Ermeniler büyük güçlerle Azeri Türklerine karşı hücuma geçtiler. Ancak Azeri Türkleri tarafından mukavemetle karşılaşınca evlere, bahçelere gizlenerek sokaklardan geçen sivil insanların üzerine ateş açtılar. Özellikle Ermeni saldırganlar Krasilnikov, Mayilov, Korsakov'un evlerinden ve Madrid Oteli'nden sokaklara silahlarla saldırdılar. Zamanın güçlü devletleri bu katliamı önlemek için hiçbir şey yapmadılar. Çatışma ve buna bağlı yangınlar 10 Şubat'a kadar devam etti. 6-10 Şubat olayları neticesinde 1000 civarında Azeri ve Ermeni ölmüştür. Bu hadiselerde mağlup olan Ermeni Taşnak silahlı güçleri hırslarını Bakü yöneticisi Nakaşidze'ye yönelttiler ve kendisi 11 Mayıs'ta Ermeni Taşnakların saldırıları sonucunda öldürüldü. ${ }^{49}$

Bakü olaylarından sonra, bütün Güney Kafkasya'da Ermeni ve Azeriler arasındaki ilişkiler gerginleşti. Mayıs'ın başında Ermeniler Nahcivan kazasında birçok Azeri Türkü'nü öldürmüş ve pek çoğunu da yaralamışlardır. 26 Kasım'a kadar taraflar arasında zaman zaman ateşkes ilan edilmiş, ancak 26 Kasım gecesi Rus Kazakları Ermeni güçlerle birleşerek saldırıya başlamışlardır. Müslümanların pazar yerini yakıp dağıtmışlar ve şehirde yaşayan Müslümanlar şehrin yöneticisi

\footnotetext{
481905 Rus Devrimi; Rusya İmparatorluğu çapında geniş yankı bulan kitlesel siyasi eylemlerdir. 1905 Moskova Ayaklanması örneğinde olduğu gibi, bazı eylemler doğrudan hükümeti hedef almıştır. Saldırılar, işçi grevleri, köylü ayaklanmaları ve askeri isyanlar şeklinde gelişmiştir. Olaylar sonucunda anayasal monarşiye geçiş yapılmış ve Çarlık Duma'sı kurulmuş, çok partili seçimler yapılmış, 1906 Anayasası meydana getirilmiştir. Ancak Çarlık rejiminin yıkılması ve bazı bölgelerdeki bağımsızlık yönünde yapılan silahlı ayaklanma girişimleri başarısız olmuş ve bastırılmıştır.

${ }^{49}$ Özçelik, Karabağ Tarihi ve Karabağ'da Ermeni Olayları, s.75-76.
}

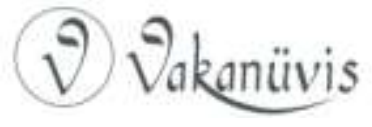


General Paskeçiç'e Kazakları şikâyet etseler de o hiçbir önlem almamış ve şehri gizlice terk etmiştir.

Cevanşir kazasında da çok kanlı olaylar yaşanmıştır. 3 Ekim 1905'te Ermeniler, Sırhavend Köyü'ne baskın yapmışlar ve insanlar ormanda saklanmak için kaçmış fakat yolda Hamazasp'ın liderlik ettiği 400 kişilik Ermeni süvarileri tarafından bunlar da öldürülmüşlerdir. ${ }^{50}$

1905 yılının karışık noktalarından biri de Şuşa olmuştur. Burada 1620 Ağustos tarihlerinde kanlı çatışmalar yaşanmıştır. Rus Kazakları ve Rus piyade birliği, Ermeni gönüllüleriyle birlikte Azeri Türklerin evlerine baskınlar yapmışlardır. Ancak Azerilerin savunması karşısında Rus Kazakları karargâhlarına, Ermenilerin bir kısmını evlerine bir kısmını da yerleşim birimlerinin dışına çıkarmayı başarmışlardır. Rus Generali Galaşaçanov, Azeri Türklerine gelerek barış için aracı olmuştur. ${ }^{51}$

Rusların bu yayılmacılığı ve gelişmeler sonucunda Türkistan ve Kafkasya'yı ele geçirmesi, İngiltere'de endişe uyandırmıştır. Bu durum Rusların Hindistan ve İran üzerinde emelleri olduğunu açığa çıkarmıştır. Ancak gelişen Alman yayılmacılığı, Rusya ile İngiltere'yi birbirine yaklaştırmıştır. 1907 yılında imzalanan Ingiliz-Rus anlaşmasına göre, İran coğrafyası nüfuz bölgelerine ayrılmıştır. Buna göre İran'ın kuzey kısmı Rus nüfuz sahası, yani Azerbaycan, Ermenistan, Gürcistan, orta kısmı tarafsız, güney kısmı da İngiliz bölgesi olarak paylaşılmıştır. ${ }^{52}$ İngiliz-Rus anlaşması Azerbaycan ve İran'ın kuzey bölgesinde Rus yayılmacılığını hızlandırmıştır.

\section{Birinci Dünya Savaşı ve Sonrasında Karabağ}

1907 İngiliz-Rus antlaşması, Azerbaycan ve İran'ın kuzey kesiminde Rus Yayıımacılı̆̆ını hızlandırmıştır. Aynı yıl İran'da başlayan milli uyanış hareketi Rusları telaşlandırmıştır. Rus çıkarlarının korunması bahanesiyle Ruslar Tahran'a asker göndermiş, İran milli meclisi topa tutularak Rus yanlısı yeni bir rejim kurulması sağlanmıştır. 1909 yılında İran'da vuku bulan devrim sonucunda İran şahı Rusya'ya sığınmıştır. 1911 yılında Şah Rus himayesinde ülkesine geri dönmüştür. İran

\footnotetext{
${ }^{50}$ Özçelik, Karabağ Tarihi ve Karabağ'da Ermeni Olayları, s.77.

${ }^{51}$ Özçelik, Karabağ Tarihi ve Karabağ'da Ermeni Olayları, s.76.

${ }^{52}$ Geniş bilgi için bkz. Dursun Yıldırım, Karabağ Dosyası, Türk Kültürünü Araştırma Enstitüsü, Yay., Ankara, 1990.
}

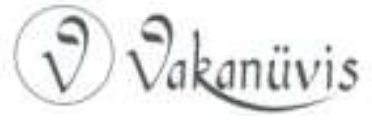


böylece adeta Rusya'nın hakimiyeti altına girmiştir. İlerleyen yıllarda Rusya Grandük Nikola'yı Kafkasya Genel Valisi tayin ederek Güney Azerbaycan'ı işgal etmiştir. (1916) Ancak Türk ordusu daha önce Tebriz'i ele geçirmiştir.

Rus işgal ve taarruz hareketi bir taraftan da Erzurum istikametinde geliş̧miş ve Ruslar buradan da ileri giderek Muş ve Bitlis'i işgal etmişlerdir. Ruslar ayrıca Trabzon ve Erzincan'ı da ele geçirmişlerdir. Ruslar bir taraftan da İran'da ilerleyerek Isfahan'ı ele geçirmişleredir. Bu gelişmelerden cesaret alan Ermeniler, Kafkasya ve Doğu Anadolu'da bir dizi isyanlar ve Müslümanlara karşı geniş bir katliam hareketine girişmişlerdir.

Geniş bir yelpazede başlayan Ermeni isyanları karşısında ne yapacağını bilemeyen Osmanlı Devleti, tedbir alma yoluna gitti ve cephelerde durumu sabitlemek ve güvenliği sağlamak amacıyla Van, Bitlis, Erzurum ve cepheye yakın başka şehirlerden Ermenileri Suriye ve Mezopotamya bölgense tehcir ettirdi. Bu olay Ermenilerce "soykırım" olarak dünya kamuoyuna anlatılmaya başlandı. Ancak Ermenilerin Türkiye topraklarında bir Ermeni Devleti hurma hayalleri gerçekleşmedi. Bu nedenle de Ermeniler, Rusya'daki Şubat devrimi ve Ekim ihtilali neticesinde Kafkasya'daki otorite boşluğunda da istifade ederek, faaliyetlerinin ağırlığını bu bölge üzerinde yoğunlaştırdılar. ${ }^{53}$ Ermeni milliyetçileri kendi stratejik maksatlarını Ermeni Devleti için Güney Kafkasya'da arazi temini yönünde gördüler. Ermenilerin çoğunun silahlanması, Rus ordusuyla paralel ya da onun içinde bulunan Ermeni lejyonlarının kurulmasıyla Ermeniler Azerbaycan Türklerine karşı üstün duruma geçtiler. Bu sırada Kafkas savaşının askeri şartlarında Rusya'ya karşı Türkiye'nin bulunduğu durum, Azerbaycan Türklerinin teşkilatlanması veya askeri kuruluşlar oluşturması oldukça zordu.

1917 yılında meydana gelen Rus ìtilali sonrasında Kafkasya'da millî istiklal hareketleri başladı. Aynı dönemde Ermeniler, Karabağ üzerinde hak iddia etmeye başladılar. Bu yüzden bozulan asayişi, 1918'de Osmanlı orduları tesis etmeye muvaffak oldu. Yaşanan Bolşevik-Taşnak ittifakı kendi hâkimiyetini yalnız Bakü ve çevresine yayabildi. 1918

53 Özçelik, Karabağ Tarihi ve Karabağ'da Ermeni Olayları, s.81.

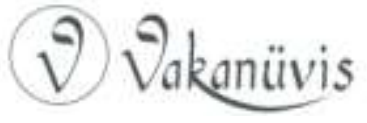


yılının Şubat'ında Güney Kafkasya'da Rusya meclisine seçilmiş olan milletvekilleri Tiflis'te Trans Kafkasya Birliğini oluşturup Güney Kafkasya Federatif Cumhuriyeti'nin kurulduğunu ilan etmişlerdi. Trans Kafkasya Hükümeti Rusya ile Almanya ve müttefikler arasında 5 Mart 1918 'de yapılan Brest-Litowsk Antlaşmasını tanımadığını bildirip anlaşma şartlarında Türkiye'ye geçmesi gereken Kars, Batum ve Ardahan'ı diğer işgal altındaki Türk topraklarını da boşaltmaktan imtina ettiğinden Trabzon'da ve daha sonra Batum'da barış görüşmeleri yapıldı. Trans Kafkasya temsilciler heyetine dâhil olan Ermeni ve Gürcü temsilciler muhtelif yollarla görüşmeleri uzatarak işgal altındaki Türk topraklarından çekilmekten imtina ediyorlardı. Bunun neticesinde Osmanlı ordusu askerî harekâta yeniden başlamak zorunda kaldı ve Sarıkamış, Kars ve Batum şehirlerini işgalden kurtardı.

Düzenli Osmanlı askeri birliklerinin önünden kaçan Ermeniler yol boyunca geçtikleri yerlerdeki Türk ahaliyi de katletmeye başladı. Çok kısa bir zaman zarfında Kars vilayetine bağlı 82 Müslüman köyü yakıldı. Ahalisinin bir kısmı öldürüldü, kalanı ise bitap haldeydi. Ermenilerle birlikte Kars'ı terk eden İngilizler şöyle yazmaktadır: "Türk ordusu karşısında geri çekilen Ermeni kaçaklar etraftaki Müslüman köylerini yeryüzünden silerek her şeyi ateşe verdiler, insanları kılıçtan geçirdiler. Tasavvur edilemez işkenceler yaptılar. 'Galip' Ermeni ordusu kaçarken, askeri ganimetleri, yani kundaktaki çocukları ve geçtikleri yolların kenarlarında çıplak soydurdukları Müslüman kadınlarını süngülerinin ucuna takıyorlardı. Bu cehennem azabından aklını kaybetmiş kadın ve çocukların yürekler parçalayan iniltilerini kocaların ümitsiz naralarını dinlemek için insanın kalbi taş olmalıdır. 82 köyden ibaret bir sancak bu tasvir edilen felakete duçar olmuştur."

Erivan bölgesine yerleşen Ermeni askeri birlikleri istikbaldeki müstakil Ermenistan için arazi temin etmek amacıyla Azerbaycan Türklerini toplu katliamlarla yok ettiler. 80.000 civarında Azerbaycan Türk'ü anayurtlarını terk etmek zorunda kaldı.

Ağustos'un sonunda Türk-Azerbaycan ordusu cephenin Lökbatan bölgesinde hücuma geçtikleri zaman İngilizler karşılarına geçmek için hareket ettiler, ancak başarısız oldular. Ahaliden mağlubiyeti gizlemeye çalışan İngilizler şehrin sokaklarında marşlar çaldırdılar. Geceleyin

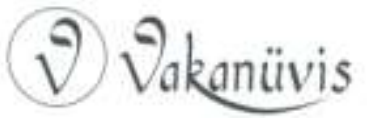


İngilizler müttefiklerinden gizlice gemilere binip 14 Eylül günü Enzeli'ye ulaştılar. 14 Eylül'de Türk-Azeri ordusu Bakü'ye girdi.

Azerbaycan'a karşı olan Ermeni tecavüzü 1918 yılının ortalarından itibaren genişlemiştir. Bu sırada ilan edilmemiş üstü kapalı bir savaşın bütün unsurları yaşanmıştır. Bu esnada Zenzegur, Karabağ, Erivan bölgelerinin bütün kazaları ve bu arazilerde komşu olan topraklarda Ermenilerin bulunduğu yerler Ermenilerce istikbaldeki Ermenistan'ın toprakları olarak düşünülmekteydi.

Dokuzuncu Kolordu Komutanı Rüştü Paşa Birinci Kafkasya İtibat Komutanlığına 20 Haziran 1918 tarihli raporunda, Erivan'ın 10 km. Doğusundaki Ağıca Kala köyünden Şorbulak yoluyla Erivan'a göç eden Müslümanların 17-18 Haziran 1918 tarihlerinde Şorbulak ve Tohmak köyü arasında Ermeniler tarafından tamamıyla yok edildiğini bildiriyordu.

Dokuzuncu Ordu Komutanı Yakup Şevki Paşa, Başkomutanlığa gönderdiği 27 Aralık 1918 tarihli telgrafında, Yanun adlı Ermeni'nin yönetiminde 1.200 kişilik bir kuvvetin 5 Aralık 1918 tarihinden itibaren Nahcivan civarındaki Müslümanlara zulmetmeye başlayarak Nahcivan'ın $40 \mathrm{~km}$. Kuzeybatısındaki Almalı bölgesinde 688 ve bu köyün 12 km. Kuzeybatısında Ağuş adlı mevkide 516 kişiyi katlettikleri, genç kadınları ayırdıktan sonra 200 kişiyi bir yerde toplayarak yaktıklarını bildirmişti.

1918 yılının Haziran-Temmuz aylarında Ermeni milislerin önde gelenlerinden Andranik, silahlı birlikleriyle Nahcivan'ı ele geçirdi ve oradan Zenzegur ve Karabağ'a doğru saldırıya geçti. Andranik, Ermeni hükümetinin 4 Temmuz 1918 tarihinde Batum'da Türkiye ile yaptığı anlaşmayı "ihanet" olarak adlandırdı. Ermenistan'ın Taşnak hükümetiyle alakasını kestiğini ve Türklerle silahlı mücadeleye devam edeceğini ilan etti. Ancak Andranik Türkiye ile açıkça savaşa girmeye cesaret edemedi. Bütün savaş kabiliyetini silahsız, müdafaasız Azerbaycan köylerini yakıp yıkmak ve ahalisini katletmeye yöneltti. Andranik yaptığı beyanatlarda Zenzegur, Karabağ ve Gence Bölgesinin Dağlık Karabağ'dan kuzeyde olan kısımlarının payitahtı Şuşa olmakla birlikte "Küçük Ermenistan"ı ilan etmişti. İstikbaldeki Küçük Ermenistan'ın topraklarında olan Azerbaycanlı ahali aralıksız teröre maruz kalmıştı.

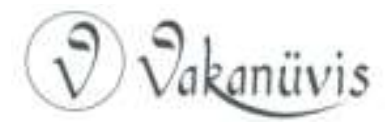


Cevanşir, Şuşa, Cebrayil ve Zengezur kazalarında Azerbaycanlı ahali Ermeni milliyetçilerinin hareketlerinden çok zararlar görüyordu. Ermeniler 1918 yılının ilkbaharında ve yazında Terter Havzası çaylarının karşısını keserek mecrasını değiştirmiş, Müslüman ahaliyi sudan mahrum bırakmıştır. Yine 1918 yılının ilkbaharı ve sonbaharı içinde Zengezur kazasında 105 Azeri köyü dağıtılmış yakılmış ve mahvedilmişti. Hesaplara göre bu zaman zarfında 3.257 erkek, 2.276 kadın ve 2.196 çocuk öldürülmüştü. Bunun yanında 1.060 erkek 794 kadın ve 485 çocuk yaralanmıştı. Toplam 10.086 insan öldürülüp yaralanmıştır. 50.000 Azeri hayatta kalabilmek için Zengezur'u terk etmek mecburiyetinde bırakılmıştı. Erivan bölgesinde Müslüman ahali acımasız teröre maruz kalmıştır. Bir daha belirtmeliyiz ki, Azeriler yeni kurulmuş Ermenistan Cumhuriyeti nüfusunun önemli bir kısmını oluşturuyorlardı.

Mondros Mütarekesini esas alarak Osmanlı Askeri birliklerinin Azerbaycan'dan çıkmasıyla Ermeni birlikleri yeniden faal duruma geçtiler. Ermeni birliklerinin tecavüzünü önlemek için 1918 yılının Kasım ayında Nahcivan bölgesinde Aras Türk Cumhuriyeti kurulmuştur. Onun arazisi Nahcivan, Şarur Dereleyez ve Ordubad kazalarını ve Serdarabad, Uluhanlı, Verdibasar, Kemerli, Mehri gibi şehirleri ihtiva etmişti. Merkezi ise Nahcivan şehriydi. Bu devlet 1919 yılının Mart'ına kadar varlığını sürdürmüştür.

Osmanlı orduları Mondros Mütarekesi gereği bölgeden çekilince, galip devletler namına İngilizler Azerbaycan'ı işgal etmiştir. İngiliz Kuvvetler Komutanlığı coğrafya, iktisat, tarih ve kültür bakımından aynılığını ve nüfusunun çoğunluğu itibariyle Türk oluşunu nazara alarak, 28 Ocak 1919 tarihli bir tebliğ ile Karabağ'ı Azerbaycan arazisine dâhil etmiştir. Millî Azerbaycan Cumhuriyeti (1918-1920) burasını bir vilayet haline getirmiştir.

Birinci Dünya Savaşı bittikten sonra Kafkasya ve Azerbaycan'da yerini sağlamlaştırmaya çalışan İngilizler kendi amaçlarına ulaşmak için Ermenilerden de istifade etmeye başladılar. Kendi açılarından Lord Curzon'un “...Elahazret hükümetinin başlıca amacı Ermenilerin azat edilmesidir" fikrinden hayat bulan Ermeniler de İngilizlerin siyasetinden faydalanmaya çalışıyorlardı.

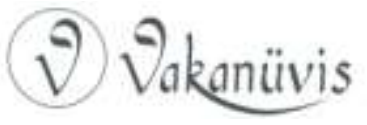


1919 yılının Şubat'ında Nahcivan bölgesine az sayıda İngiliz askeri getirildi. Aynı zamanda Ermenistan'ın komşu bölümleri ZengezurNahcivan- Karabağ bölgelerine tecavüzünü daha da genişletti. İngilizler Nahcivan bölgesini geçici olarak tarafsız bölge ilan ederek burada kendi askeri yönetimlerinin kurulduğunu ilan ettiler.

Karabağ ve Zengezur'a dair iki başlı ve birbirine ters siyaset yürüten Ingilizler Azerbaycan'ın bu bölgelere hukuklarını resmen tanısalar da bölgelerde hâkimiyet aslında Azerbaycan'a değil Ermeni milli şurasına vermiş, hatta Ermeniler'in Karabağ ve Zengezur'da kuvvetlenmesine mâni olan bir şahıs gibi Hüsrev Bey'i vazifesinden uzaklaştırmaya niyet etmişlerdir.

İngilizlerin Kafkasya'yı tahliyesinden sonra Ermenistan'ın sık sık yaptığı silahlı saldırılarına Azerbaycan hükümeti karşı koymak zorunda kalmıştır. 28 Nisan 1920 tarihinde Azerbaycan'da Sovyet yönetim ilan edildi. Karabağ ve şu anda Ermenistan sınırları dâhilinde bulunan Zengezur, ilan edilen Azerbaycan Sosyalist Cumhuriyeti'nin topraklarıydı. Fakat tarih boyunca amaçlarına ulaşmak için hep Ruslarla iş birliği yapan Ermeniler, Azerbaycan'da Rus yanlısı yönetim kurulmasını bir fırsat olarak gördüler ve Karabağ'a ilişkin iddialarını daha yüksek sesle dile getirmeye başladılar. Illk başlarda daha Ermenistan, Sovyet Rusya ile birleşmediği için Sovyet yönetimi bu tür meselelerde biraz Azerbaycan yanlısı tutum takınarak Ermenistan'a baskı yapmaya çalışıyordu. Bu arada eğer Ermenistan'da Sovyet yönetimi kurulursa bunun karşılığında Karabağ ve Zengezur'la ilgili olarak bir takım vaatler de veriliyordu. Bunun en önemli örneklerinden birisi Lenin'in "Doğu'nun Lenin'i" diye nitelendirdiği bağımsız Azerbaycan Halk Cumhuriyeti'nin millî yöneticileri tarafından her zaman ihanetle suçlanan ve sonraları Moskova'da zehirlenerek öldürülen dönemin Azerbaycan Sovyet yönetiminin başı Neriman Nerimanov tarafından Ermenistan komünistlerine gönderilen bir telgraftı. 1 Aralık 1920 tarihinde gönderilen bu telgrafta Ermenistan'da Sovyet yönetimi kurulması karşılı̆̆ında Azerbaycan'ın Nahcivan, Zengezur ve Karabağ'ı ona verilebileceği ifade ediliyordu.

Tartışmalar devam ederken Azerbaycan'da Rusça yayımlanan "Komünist" gazetesinin 2 Aralık 1920 tarihli sayısında Nerimanov adına bir bildiri yayımlandı. Bildiride arazi meseleleri yüzünden iki komşu

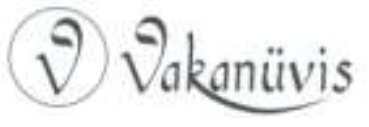


halkın kanının akmaması gerektiği ve Karabağ emekçilerinin kendi kaderlerini belirleme hakkının bulunduğu ifade ediliyordu. Ermenistan'da Sovyet yönetiminin kurulması dengeleri biraz değiştirdi. Ermenistan Sovyet yönetiminin liderleri Karabağ'a ilişkin iddialarını Moskova'ya ilettiler ve Komünist Partisi Kafkas bürosunda dile getirdiler. Bu iddialar üzerine önce 27 Haziran 1921'de Azerbaycan Komünist Partisi Merkez Komitesi toplanarak Ermenilerin iddialarını reddettiler ve Karabağ'ın Azerbaycan'dan koparılamayacağını ifade ettiler. 4 Temmuz 1921 'de toplanan Kafkas Bürosu (Kafkas Cumhuriyetlerindeki Komünist Partilerinden oluşuyordu ve 7 üyesinden sadece bir tanesi Azerbaycanlı idi) Dağlık Karabağ'ın Ermenistan'a verilmesi konusunda görüş bildirdi. Tüm değerlendirmeler yapıldıktan sonra Orconikidze ve Nazaredyan'ın önerisiyle "Müslümanlar ve Ermeniler arasında millî sulhun gerekliliği, Yukarı ve Aşağı Karabağ'ın iktisadî alakasının zaruriliğine, onun Azerbaycan'la olan daimi bağlantısı gibi hususlardan hareketle Dağlık Karabağ'ın Azerbaycan Sovyet Sosyalist Cumhuriyeti sınırları içinde kalmasına, bölge dâhilinde bulunan Şuşa şehrinin idarî merkez olmak üzere bölgeye geniş bir özerklik verilmesine" karar verildi. Böylece, Azerbaycan'ın bir üyeyle temsil olunduğu toplantıda Ermenilerin de onayıyla Karabağ'ın Azerbaycan'dan koparılamayacağı karara bağlanmış oldu. Kirov, Moskova tarafından Azerbaycan yönetiminin başı olarak atandı. Yapılan görüşmeler sonucunda 7 Temmuz 1923'te Azerbaycan Merkezî Yürütme Komitesi Dağlık Karabağ Özerk Bölgesinin oluşturulması kararını aldı.

Türkiye Büyük Millet Meclisi ve Rusya arasında imzalanan 1921 Moskova Anlaşması ile, Zengezur Ermenistan'a ilhak edilmek şartıyla Karabağ ve Nahcivan Azerbaycan'a iade edilmiştir. 1923'te, merkezi Şuşa civarındaki Hankendi olmak üzere, Karabağ'ın dağlık kısmından ibaret olan kısmında, Azerbaycan idaresinde muhtar bir Ermeni vilayeti teşkil olunmuştur.

Coğrafya, iktisat, idare ve kültür bakımından Azerbaycan'ın ayrılmaz bir parçası olan ve Dağlık Karabağ adını taşıyan bu muhtar vilayet, asıl Karabağ arazisinin dörtte birinden de az olan $4.200 \mathrm{~km}^{2}$ bir saha üzerinde 150.000 (1933) nüfusu ihtiva etmekteydi. Rusların Ermeniler

\section{(2) Vakaniuivis}


lehinde izlediği politikanın bir uzantısı olarak bu nüfusun $\% 65-70$ 'i Ermeni'ydi.

Muhtar Ermeni sahasını dört bir yandan saran ve nüfusları \%100 Türk olarak gösterilen Ağdam, Cebrail ve Laçin kazaları ile civar bölgeler, o dönem Bakü'ye bağlı yeni bir taksimata tabi tutulmuştur. Araplardan evvel ve Arap hâkimiyeti sırasında Müslüman şarkın Bağdat'tan sonra en büyük şehri sayılan Berda, 20. yüzyılda küçük kasaba halinde bir nahiye merkezi olmuştur. Aynı devirlerde iktisadî ve medenî bir merkez olan Beylakan'ın Cebrail kazası dâhilinde olduğu sanılmaktadır. Yine, Karabağ'ın bir zamanlar 60-70.000 nüfuslu, önemli bir yeri ve hanlığa merkezlik yapmıs olan şehri Şuşa, 5-6.000 nüfuslu bir şehir haline getirilerek Ermeni sahasına dâhil edilmiştir. ${ }^{54}$

1828 yılında İran ile Rusya arasında imzalanan Türkmençay Antlaşması ile Kuzey Azerbaycan ve Karabağ, Rusya'nın yönetimine dâhil olmuştur. Bu tarihte Karabağ nüfusunun 200.000 olduğu ve bunun \%95'ini de Türklerin teşkil ettiği bilinmektedir. Rusya, Azerbaycan ve Karabağ'da nüfus yoğunluğunun Türkler lehinde olmasından rahatsızlık duymuş ve muhtelif yerlerden getirdiği Ermenileri bölgeye yerleştirmiştir. Bununla birlikte, I. Dünya Savaşı sırasında Osmanlı tebaası olan, savaş esnasında Rusları destekleyen ve Türkleri arkadan vuran Ermeniler de, Türkiye Cumhuriyeti'nin kurulmasıyla Anadolu topraklarını terk etmiş, Ruslar bunların büyük bir kısmını Karabağ'a yerleştirmiştir. Ruslar ve Ermeniler bu tarihten itibaren Karabağ'a,

"Dağlık Karabağ" (Nogarno Karabagh) adını vermişlerdir. Bundan sonra da Rusların da desteğiyle Karabağ'da meskûn Türklere karşı tedhiş faaliyetlerinde bulunmuşlardır. Bu sahadaki Türkler de Azerbaycan ve değişik yerlere göç etmek zorunda kalmışlardır. Böylelikle Karabağ'da nüfus Ermeniler lehine değişmiştir.

Olayların tırmandığı 1980'li yıların ortalarına gelinceye kadar, Ermeniler çeşitli yollarla ve çeşitli düzeylerde Karabağ bölgesinin Azerbaycan'dan alınarak kendilerine verilmesi gerektiğini ifade etmişlerdir.

${ }^{54}$ Bala, a.g.m., s. 216.

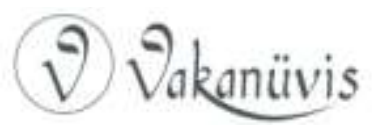




\section{Sonrası Karabağ Olayları}

1980'li yılların birinci yarısında bölgeden olan Ermeni asıllı yazarlar, yazılarının sonunda adres olarak "Ermenistan'ın Karabağ bölgesi" notunu düşmeye başladılar. 1985 yılında SSCB yönetimin başına M. Gorbaçov'un geçmesiyle birlikte, yeni bir dönem-"perestrokya (yeniden yapılanma) ve glastnost (açıklık) dönemi- başladı. Bir yandan dışarıdaki Ermeni lobisinin, diğer yandan da SSCB içindeki Ermeni aydınların Gorbaçov'la geliştirdiği ilişki, onları Azerbaycan'ın Karabağ bölgesini alabilmeleri konusunda umutlandırıyordu. İlerleyen dönemlerde ister Gorbaçov'un ekonomi danışmanı Aganbekyan'ın Paris'te yaptığı konuşma, isterse de Ermenistan'da ve Moskova'daki Ermeni faaliyetleri, Karabağ bölgesini bir an önce Azerbaycan'dan koparmaya yönelikti. Bu arada, bölgede yaşayan Ermenilerde artık daha aktif bir pozisyona gelmişlerdi.

20 Şubat'ta Dağlık Karabağ Özerk Bölgesi Bölge Sovyeti (140 üyesinden 110'u Ermeni idi) Azerbaycan ve Ermenistan Yüksek Sovyetlerine hitaben, Azerbaycan'dan ayrılarak Ermenistan'la birleşme istediğini belirten müracaatı kabul etti. 21Şubat'ta toplanan Sovyetler Birliği Komünist Partisi Merkez Komitesi Ermenilerin isteklerinin gerçekleşmeyeceği kararını aldı. Azerbaycan'ın Dağlık Karabağ Özerk Bölgesi içinde yer alan Askeran rayonunda iki Azerbaycanlı gencin öldürülmesi, Ermenistan gazetelerinde güya Gorbaçov'un Karabağ'ı onlara vereceği sözünü vermesi iddialarının yayınlaması ve Ermenistan'da (Zengezur, Göyce ve başka bölgelerden) yaşayan yüz binin üzerinde Azerbaycan Türkünün katliamlara maruz kalması ve göçe zorlanması (sürecin sonunda toplam 160 bin Azerbaycan Türkü Ermenistan'ı terk etmek zorunda kalmıştı), bu göçe zorlananların da genellikle Bakü ve Sumgayıt'a yerleşmesi sonucu özellikle, bu iki kentte Ermenilere karşı saldırılar düzenlendi. Sumgayıt'taki saldırılarda 6'sı Azerbaycanlı, 26'sı Ermeni olmak üzere 32 kişi öldü.

12 Temmuz 1988'de Dağlık Karabağ Özerk Bölgesi Yerel Meclisi, Azerbaycan'dan ayrılma kararı aldı. Ertesi gün toplanan Azerbaycan Yüksek Sovyeti Başkanlık Divanı yerel meclisin kararını geçersiz ilan etti. Gelişmeler üzerine 18 Temmuz'da toplanan SSCB Yüksek Sovyeti Başkanlık Divanı, her iki cumhuriyetin kararlarını değerlendirdi ve karar aldı. Değerlendirmeler sırasında konuşma yapan $M$. Gorbaçov,

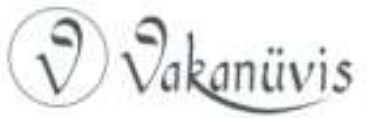


Karabağ'ın sorunlarının varlığını kabul ettiklerini, fakat bu sorunların Azerbaycan'ın toprak bütünlüğüne dokunulmadan çözüleceğini ifade etti. 20 Temmuz 1988 tarihli "Kommunist" (Bakü) gazetesinde yayınlanan kararda, Azerbaycan ve Ermenistan'ın sınırlarının ve anayasayla belirlenen toprak bütünlüğünün değiştirilmesinin mümkün olmadığı, bu kararın SSCB Anayasasının 78.maddesine (herhangi bir Sovyet Cumhuriyetinin sınırı,onun rızası olmadan değiştirilemez) dayandığı ifade ediliyordu.

7 Aralık 1988'de Ermenistan'da olan deprem, olayları kısa bir süre için durdurdu. 12 Ocak 1989'da, Sovyetler Birliği Yüksek Sovyeti Dağlık Karabağ Özerk Bölgesi'nin yönetimini geçici bir süre için Azerbaycan'dan alarak Moskova'ya bağı Özel Yönetim Komitesi'ne verdi. Gorbaçov'un danışmanlarından olan A. Volski komitenin başına getirildi ve 5.400 kişilik İçişleri Bakanlığı Birliği ona bağlanarak gölgeye gönderildi. 1989 yılı boyunca çatışmalar küçük çaplıda olsa ara vermeden devam etti.

28 Kasım 1989'da Sovyetler Birliği Yüksek Sovyeti Dağlık Karabağ Özerk Bölgesi yönetiminin yeniden Azerbaycan'a bırakılmasına, fakat güvenlik güçlerinin orada kalmaya devam etmesine, Karabağ'da ki Ermenilerin haklarının korunması için gerekli yasal düzenlemelerin yapılması şartıyla karar verildi. Karar, Karabağ'ın Azerbaycan toprağı olduğunu bir daha onayladığı için Ermenilerce, Karabağ konusunda Azerbaycan'a bazı dikteler ettiği için de Azerbaycan tarafından eleştirildi. Ermenistan daha da ileri giderek 1 Aralık 1989'da Karabağ'ı kendisine birleştirme kararı aldı. Bunun üzerine 7 Aralık 1989'da Azerbaycan Yüksek Sovyeti, Ermenistan Parlamentosu'nun aldığı Dağlık Karabağ Özerk Bölgesi ilhak kararını kınadı ve Karabağ'ı yönetmek üzere Egemenlik Yasasına (23 Eylül 1989'da kabul edilen bu yasada Karabağ üzerinde Azerbaycan'ın egemenliği de ayrıca vurgulanmıştır) dayanarak başkanlığını Azerbaycan Komünist Partisi ikinci sekreteri V. Polyaniçko'nun yaptığı "Teşkilat Komitesini" kurdu.

2 Ocak 1990'da Dağlık Karabağ Özerk Bölgesi'nin Merkezi Hankendi'nde Azerbaycan Türklerini taşıyan otobüs konvoyu Ermenilerin saldırısına uğradı. Güvenlik güçleri saldırıyı önledi ve olaylar sırasında 1 kişi öldü, 3 kişide yaralandı. 9 Ocak'ta Ermenistan Parlamentosu'nun 1990 bütçesini onaylarken ekonomik plan 
kapsamında Karabağ'ı da dahil etmesi olayları çığııından çıkardı. Azerbaycan'da hem Moskova yönetimine hem de Azerbaycan yönetimine karşı protesto gösterileri arttı.

12 Ocak'ta Ermenilerin Karabağ'da ki iki Türk yerleşim birimine saldırmaları sonucu, 12 kişi öldü, 22 kişi rehin alındı. 13 Ocak'ta, bir Ermeni Bakü'de iki Azerbaycanlıya baltayla saldırdı. Saldırıya uğrayanlardan birisi öldü, diğeri ağır yaralandı. Bu haberin o sıra gerçekleşmekte olan büyük bir mitinge ulaşması üzerine karşı saldırı düzenlendi ve bu saldırı sırasında büyük çoğunluğu Ermeni olmak üzere 34 kişi hayatını kaybetti. Olayların daha da trajik boyut kazanmasını neden gösteren Moskova yönetimi, Bakü'de ve Azerbaycan'ın birçok başka bölgesinde (Dağlık Karabağ Özerk Bölgesi dahil) olağanüstü hâl uygulaması başlattı. 19 Ocak 1990 tarihinde akşam saatlerinde olağanüstü hâl ilan edilirken, aynı saatlerde Kızılordu Birlikleri havadan, karadan ve denizden Azerbaycan'a çıkartma yaptı. Amacı daha çok Azerbaycan'da ki bağımsızlık yanlılarını ezmek olan çıkartma sonucunda, 367 Türkün öldüğü ve yüzlercesinin yaralandığı tespit edilmiştir. Bu savaş, SSCB'de komünizmin çöküşünü hızlandırmış; Azerbaycan Türklerinin tam bağımsız bir devlet olmalarını sağlamıştır.

1991 yılında, SSCB'nin dağılmasına müteakip meydana gelen otorite boşluğu Ermenilerin bu arzularını sınır çatışmalarına dönüştürmüştür. Orta çaplı çatışmalar, iki tarafın sürekli birbirini suçlaması ve merkezi yönetimin gerekli önlemleri almaması yine devam ediyordu. 1991 Mart'ı ortalarında Gorbaçov, "Tass" ajansına yaptığı açıklamada bölgedeki çatışmalardan duyduğu rahatsızlığı ve "Karabağ'ın Azerbaycan'ın ayrılmaz bir parçası" olduğunu ifade etti. Bu açıklamadan sonra basın toplantısı düzenleyen Ermenistan Başbakanı Vazgenmanukyan, o güne kadar izledikleri politikanın aksine Karabağ'ın üzerinde bir hak iddia etmediklerini, sadece oradaki yerli Ermenilerin mücadelesini desteklediklerini beyan etti.

Ağustos ayı ortalarında Gorbaçov'a karşı düzenlenen darbenin başarısız olması ve bunun sonucunda Sovyet Cumhuriyetleri'nin bağımsızlaşmasının hızlanması, Karabağ Sorununa yeni bir boyut kazandırdı. 30 Ağustos 1991 'de Azerbaycan bağımsızlığını ilan etti. Bunun ardınca Karabağ Ermenileri toplanarak, "Artsak Ermeni

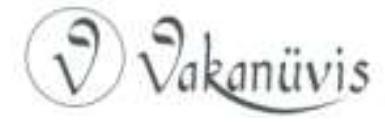


Cumhuriyeti"ni ilan ettiler. Azerbaycan Parlamentosu karara, Azerbaycan Anayasasına (aynı zamanda SSCB Anayasasına) aykırı olduğu için tepki gösterdi. 20 Eylül 1991'de Ağustos Moskova Olaylarının muzafferi Yertsin yanına, öteden beri bu olaylarla yakından ilgilenen Nazarbayev'ide alarak 20 Eylül 1991'de geç saatlerde Bakü'ye geldi. Ertesi gün Gence kentine giden liderler, burada yeterli güvenlik önlemleri alındıktan sonra Karabağ'ın merkezi Hankendi'ne geçtiler. Son durak ise, Erivan oldu. Yertesin ve Nazarbayev, bir barış sürecini başlatmaya çalıştılar ve her iki tarafla yaptıkları görüşmelerde bunun şartlarını yaklaşık olarak belirlediler. Uzlaşma üzerine, 23 Eylül 1991'de Rusya'nın güneyindeki Jeleznovodsk kentinde barış görüşmelerine başlandı. 24 Eylül 1991'de Yeltsin ve Nazarbayev'in garantörlüğünde iki ülke anlaşmaya vardı. Buna göre, ateşkes sağlanacak, Ermenistan Karabağ'ın Azerbaycan'a ait olduğunu kabul edecek, bölgeye kendini yönetmesi için bir takım olanaklar sağlanacaktı.

Görüşmelerin ikinci ayağı iki taraf yetkilerince, sınırdaki İcevan rayonuna bağlı bir köyde gerçekleştirildi. Görüşme sonrası yayınlanan bildiri de "Cinayet ve İntikama dayanan kısır döngünün durdurulmasının zorunlu oldu" bildirildi. Fakat, bu arada karşılıklı saldırılara da ara verilmiyordu. Azerbaycan tarafı ateşkese uyulmadığını göstermek üzere Rusya ve Kazakistan'dan bölgeye gözlemcilerde getirdi. 20 Kasım 1991'de çok önemli bir olay gerçekleşti. Azerbaycan hükümetinin üyelerini, adalet ve güvenlik yetkililerini, iki Rus generalini, Kazak ve Rus gözlemcileri, gazetecileri taşıyan helikopter Ermeniler tarafından düşürüldü. Bu olay, Azerbaycan tarafını bir takım kararlara itti. Ermenistan'a giden demiryolu kapatıldı, ayrıca Azerbaycan Yüksek Sovyeti 26 Kasım 1991 tarihli toplantısında Dağlık Karabağ Özerk Bölgesinin statüsünü ortadan kaldırdı ve onu oluşturan rayonları direkt Bakü'ye bağladı.

1992 yılının şubat ayında Avrupa Parlamentosu Strazburg'da toplanarak Karabağ'a gözlemci gönderme kararı aldı. 20 Şubat 1992'de Rusya Dışişleri Bakanlığı'nın girişimi ile üç ülke (Azerbaycan, Rusya ve Ermenistan) Moskova'da bir araya geldiler ve yaptıkları görüşme sonrasında düzenledikleri basın toplantısında çatışmalara bir an önce son verilmesi ve yerleşim bölgeleri üzerinde ki ablukanın kaldırılması hususunda bir karara vardıklarını açıkladılar. 
25-26 Şubat 1992 'de Ermeni güçlerinin bölgedeki yerleşim birimi Hocalı'ya düzenledikleri saldırı bir katliama dönüştü. Tarih, 25/26 Şubat 1992.Yer Hocalı.dır. Dağlık Karabağ'ın güzel bir kasabası...Sovyetler Birliği'nin yıkılışından sonra, Rusya'dan kopan halklar, kendi bağımsızlıklarını yeniden elde ediyorlar. Ermenistan ve Azerbaycan da bağımsızlıklarına yeniden kavuşmuşlar...Ancak Karabağ? Azerbaycan'dan koparılıp alınan bir bölgedir. Rusya ile iş birliğine girmekten çekinmeyen Ermeniler tarafından yutulmaya karar verilmiş. Ermeniler hiçbir değer, kural; vicdani yükümlülük tanımadan, her türlü katliamı yaparak; bu kadim Türk topraklarını yutmak için harekete geçmişlerdi. Soğuk bir Şubat gecesi...Bölge Ermeni askerleri tarafından sarılmış. Insanlar evlerinde; soğuk ölümün o kadar kendilerine yaklaştığından habersizdirler. Sonra yavaş yavaş; Hocalı'ya askeri hareket başlıyor... Ermeniler, planlarını çoktan kurmuşlardır. Asker görünümlü Ermeni çeteler, önlerine gelen hedeflere ateş etmekten geri kalmıyorlar. Neye uğradığını şaşıran sivil halk, kendini sokaklara atarak, ölümden kaçmaya çalışıyorlar. Ancak nereye? Ve nasıl? Bir tek kaçış yolu var: Oda doğu yönü...

Ve halk panik içinde. Yaşlı, çoluk çocuk; yollara dökülerek; yakındaki Ağdam Kasabası'na ulaşmak için kaçışıyorlar...Yukarılara çıkıp; kırsal bir alana geldiklerinde; içinde pek çok eski Asala militanlarının da bulunduğu Ermeniler tarafından kuşatılıyorlar. Silahlar patlıyor. Sekiz yüze yakın günahsız insan acımasızca öldürülüyor. Bu öylesine bir utançtır ki; sonradan haber ajansları görüntüleri dünya kamuoyuna servis ettiklerinde, insanlık utancından yüzünü kapatıyor. Örneğin küçük bebekler; karınları parçalanarak öldürülmüşler... Silahsız yaşlı, genç erkeklerin kafatasları parçalanırcasına; kafa derileri yüzülmüş...Kadınların mahrem yerleri kesilip; hayâsız görüntüler ortaya konulmuş, göbekleri üzerinde ateşler yakılmış...Gençlerin gözleri oyulmuş; kemik parçaları orta yerde...

Saldırıda 600'den fazla sivil öldürüldü. Bunlardan 63'ü çocuk, 106'sı kadın, 70'i yaşlı idi. Ayrıca 487 kişi Ermenilerce rehin olarak götürüldü, 1275 kişi yaralandı, 150 kişiyle ilgili olarak ise hiçbir şekilde bilgi edinilemedi. Azerbaycan resmi olarak, Hankendi'ndeki 366. Rus Alayının saldırıya katıldığını açıkladı. Ermenilerin ve Rusların ortaklaşa gerçekleştirdikleri bu katliam, kendi halkını korumak için yeterli önlem

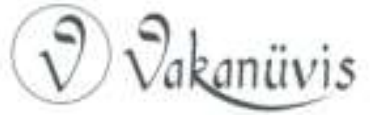


almayan Azerbaycan Cumhurbaşkanı A. Mütellibov'un iktidarının sonunu da hazırladı. Mart ayı boyunca karşıııkı saldırılar devam ederken, 24 Mart 1992'de Helsinki'de toplanmakta olan AGik Dışişleri Bakanları Konseyi, Karabağ'da ki durumu değerlendirdi ve sonuç bildirisinin 3.- 11. maddelerinde sorunun çözümü için Beyaz Rusya'nın Minsk kentinde konferans çağrılmasının kararlaştırıldığını açıkladı.

9. maddede konferansın katılımcıları olarak Azerbaycan, Almanya, $A B D$, Ermenistan, Beyaz Rusya, İsveç, İtalya, Fransa, Türkiye, Çek ve Slovakya Federal Cumhuriyeti (toplam 11 devlet) belirlendi. Minsk Konferansı için koordinatörlük görevi İtalya'ya verildi ve konferansa başkanlık etmek üzere İtalyan temsilcisi Mario Rafaelli atandı. Konferans temmuz ayında Minsk'te yapılacaktı. AGiK'in bu girişimi BM'den de destek gördü. BM Güvenlik Kurulu, 26 Mart tarihli toplantısında, soruna direkt müdahale etmeme ve AGIK'in girişimini destekleme kararı aldı.

1 Nisan'da Roma'da konferansa katılacak ülkelerin temsilcilerinin katıımı ile Rafaelli başkanlığında toplantı yapıldı. Aynı günlerde AGik gözlemci heyeti de Bakü'yü ziyaret etti. Nisan sonuna doğru İran'ın arabuluculuk girişimleri de arttı ve 7 Mayıs 1992'de, Tahran'da Azerbaycan ve Ermenistan devlet başkanları sorunun çözümü ile ilgili antlaşma imzaladılar. Fakat hemen ertesi gün Ermeniler bölgedeki en stratejik noktayı, Şuşa kentini işgal ettiler. Üzerinden 10 gün geçmeden bu defa da Dağlık Karabağ'ı Ermenistan'a bağlayan Laçin rayonunu işgal ettiler. Olaylar aynı günlerde barış görüşmeleri için bölgeye gelen AGiK heyetinin gözleri önünde cereyan ediyordu. $\mathrm{Bu}$ arada Azerbaycan'da yönetime gelen yeni iktidar Karabağ'da dahil olmak üzere bütünlüğü konusunda hiç taviz vermeyeceğini ilk başta açıkladı ve ilk sınavını da 21 Mayıs 1992 tarihinde Helsinki'de gerçekleşen AGiK Kıdemli Memurlar Komitesi toplantısında verdi. Bu toplantıda Ermenistan'ın son saldırıları da değerlendirildi. ABD temsilcinin önerdiği, Azerbaycan'ın toprak bütünlüğünü vurgulan ve bölgedeki tüm yabancı askeri güçlerin çekilmesini öngören tasarı için, Ermenistan dışındaki 51 ülkenin temsilcisi lehte oy kullandı. Aynı tarihte Ermenistan Rusya ile 7. Rus Askeri Üssünün cumhuriyette kalması konusunda antlaşma imzaladı. Buna bir de Ermenistan'ın BDT üyesi olmasını ve 15 Mayıs'ta imzalanan BDT Ortak Güvenlik Paktı

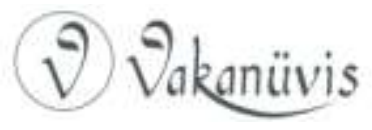


Antlaşmasına Azerbaycan'ın katılmadığını göz önünde bulundurursak, Rusya'nın desteğini alma bakımından Ermenistan'ın önemli bir avantaj elde ettiğini söyleyebiliriz. Bundan cesaret alan Ermenilerin büyük çaplı bir harekât planladıkları duyumları alınmaya başladı. Bunun üzerine Azerbaycan 12 Haziran'da karşı saldırı başlattı.

Bu gelişmeler sonrasında Ermenistan temsilcilerinin barış görüşmelerine Karabağ Ermenilerinin resmi sıfatla katılmalarını istemesi ve aksi takdirde toplantılara katılmayacağını söylemesi üzerine 29 Haziran- 7 Temmuz arasında yapılacak olan Roma görüşmelerinden istenilen sonuç elde edilemedi. Ermenilerin görüşmeleri engelleyici tutumu katılımcılar tarafından tepkiyle karşılandı.

26 Ağustos 1992'de Kazakistan Devlet Başkası Nazarbayev ateşkes ilan edilmesi için girişimde bulundu. 27 Ağustos'ta ise Minsk Grubu başkanı Mario Rafaelli sırasıyla Azerbaycan'ı ve Ermenistan'ı ziyaret ederek ateşkes yapılması ve Minsk Konferansı için görüşmelere başlanması çağrısını yaptı. İlk sonuçlar Azerbaycan, Ermenistan ve Kazakistan dışişleri bakanları arasında 27 Ağustos 1922'de Alma-Ata Beyannamesinin imzalanmasıyla elde edildi. Bu beyannamede öngörüldüğü üzere, 1 Eylül 1992'den itibaren ateşkes sağlandı. 3 Eylül 1922 'de taraflar Minsk Grubu'nun da çağrılarına uyarak bu belgeyi imzalamak için sınırdaki İcevan rayonunda protokol imzaladılar. 12-15 Eylül 1992 tarihlerinde üç taraflı çalışma grubu faaliyete geçti. Fakat, bu defa da Ermenistan Alma-Ata Beyannamesini reddetti ve Kazakistan'ın ikna çabaları sonuçsuz kaldı.

1993 yılının hemen başında 3 Ocak'ta Kremlin'de bir araya gelen ABD Başkanı George Bush ile Rusya Devlet Başkanı Boris Yeltsin, Dağlık Karabağ'a ilişkin olarak imzaladıkları beyannamede Dağıık Karabağ'da ve Azerbaycan-Ermenistan sınırındaki çatışmalardan rahatsızlıklarını ifade ediyor ve sorunun AGiK'in temel ilkeleri çerçevesinde çözümlenmesini gerektiğini vurguluyorlardı. Bunun karşılığında ise çatışmanın her iki tarafı yine sorunun çözümlenmemesinin nedeni olarak diğerini gösteriyordu.

20 Şubat 1993'te Roma'da Azerbaycan, ABD, Ermenistan, Rusya temsilcileri ve Minsk Konferansı Başkanı Rafaelli'nin katıldı̆ı Roma Görüşmeleri devam etti. Müzakereler devam ettiği sırada 27 Mart

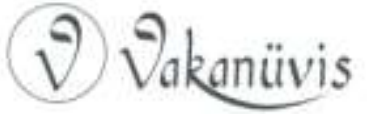


1993 'te Ermenistan, Azerbaycan'la Dağlık Karabağ bölgesini bağlayan koridorlardan biri olan Kelbecer rayonuna yönelik saldırı başlattı. Saldırılar birkaç gün sürdü. Azerbaycan Cumhurbaşkanı 6 Nisan 1993 'te, 3 Nisan 1993 'te itibaren rayonun tamamen Ermeni güçleri tarafından işgal edildiği resmi olarak açıklandı. Saldırı da rayon nüfusunun bir kısmı öldürüldü, kalanlarsa mülteci durumuna düştü. Azerbaycan taraf bu işgal sırasında Ermenistan tarafının Rus askeri birliklerinden destek gördüğünü iddia etti. 6 Nisan 1993'te ABD'de Ermeni saldırısı kınadı. Bu arada Azerbaycan tarafı AGiK barış görüşmelerinden çekildiğini de açıkladı. 8 Nisan'da AT'na üye ülkeler de "Azerbaycan topraklarından çekilmesi" ve çatışmaların durdurulması konusunda "Dağlık Karabağ'da nüfuzunu kullanması için" Ermenistan hükümetine müracaat ettiler. Olayla ilgili açıklama yapan Ermenistan Savunma Bakanı Vazgen Manuktan Kelbecer'in işgaline Ermenistan ordusunun hiç katılmadığını, olayın Karabağ Ermenilerince gerçekleştirildiğini iddia etti.

6 Nisan 1993'te Güvenlik Konseyi dönem başkanı Marker, Güvenlik Konseyi'nin Azerbaycan ve Ermenistan arasındaki durumun kötüleşmesinden, Kelbecer'in işgalinden bölgedeki barışı tehdit eden hareketlerden duyduğu rahatsızlığı; sınırların değişmezliği ve toprak bütünlüğü ilkeleri çerçevesinde AGiK'in barış girişimlerini desteklediğini açıkladı. Ayrıca BM Genel sekreterinden konuyla ilgili Güvenlik Konseyi'ne raporlar sunmasını istedi. 14 Nisan 1993'te Genel Sekreter tarafından sunulan raporda, Karabağ'daki çatışmalara ve özellikle Kelbecer'in işgaline Ermenistan'ın taraf olarak katılıpkatılmadığının tam olarak belirlenmediğini; fakat saldırılarda tank, ağır çaplı silahlar ve uçakların kullanılmasının, olayda yerel Ermeniler dışında güçlerinde bulunduğunu belirtmiştir.

23 Nisan 1993'te Rusya Devlet Başkanı Yeltsin BM Güvenlik Konseyi'nde, sorunla ilgili olarak arabuluculuk yapacaklarını ifade ediyordu. Arkasından hem Ermenistan, hem Azerbaycan yetkilileriyle, hem de Karabağ bölgesi temsilcileriyle görüşmeler yapıldı. Bunu 28-29 Nisan 1993 tarihlerinde Prag'da gerçekleştirilen AGiK toplantısı izledi. Azerbaycan'ın Kelbecer'i boşaltması yönünde adım atmasının şart olduğu vurgulandı. Ermenistan'ın bunu reddetmesiyle görüşmelerden sonuç alınamadı.

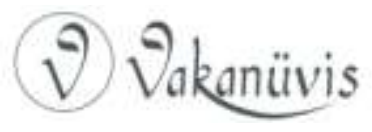


3 Mayıs 1993'te Rusya Devler Başkanı Yeltsin'in insiyatifiyle Rusya, Türkiye ve ABD, AGiK süreci çerçevesinde bir barış girişimi başlattıklarını açıkladılar. Rusya'yı Ermeni yanlısı olarak gören Azerbaycan, durumu dengelemek için eşit güve sahip ülke olarak ABD'nin sürece katılmasını istemişti. Tarafların, 14 Mayıs 1993'e kadar Ermeni güçlerinin Kelbecer'i boşaltmasını, 17 Mayıs 1993'ten itibaren de AGiK çerçevesinde barış görüşmelerinin devam ettirilmesini öngören teklifleri Azerbaycan tarafından kabul görse de, Ermenistan buna yanaşmadı. Böylece barış görüşmeleri sürecini tıkadılar.

Bunun yanında Azerbaycan'daki karışıklıklar ve iktidar boşluğu barış görüşmelerini tıkamakla kalmadı, Ermenilerin yeni saldırılarını da beraberinde getirdi. Daha çok iç karışıklıklarla uğraşmak zorunda kalan Azerbaycan, Ermeni saldırıları karşısında fazla tutunamadı. 1993 sonuna kadar Ermeni işgalleri sonucunda Akdere, Ağdam, Cebrayıl, Fizuli, Gubatı'ının, Ekim ayında Horadiz, Zengilan'ın ve Karabağ'ın işgaliyle Karabağ'ın Türkiye'ye en yakın şehri olan Laçin'i fiilen Azerbaycan kontrolünden çıkararak Ermenilerin eline geçti. Yıl sonuna kadar çatışmalar zayıflayarak devam etti.

8 Mayıs 1994'te Moskova'da imzalanan "Bişkek Protokolü" ile Ermenistan ve Azerbaycan arasında ateşkes imzalanmıştır. Bütün bu yapılanlar, bölgenin sahip olduğu jeopolitik ve jeostratejik öneminden kaynaklanmaktadır. Zira maşa bir Ermenistan devleti ile Kafkasya'ya hâkim olmak isteyen Rusya için Karabağ önemli bir mevkie sahip olmuştur. Karabağ'a sahip olanın Kafkasya'ya sahip olmak anlamına geldiğini bilen Ruslar, devamlı bölgeye hâkim olmak istemiştir. Denilebilir ki Ermeniler bölgeye yönelik emellerinin arkasında da bu gerçekler gizlidir.

\section{Sonuç}

XVIII. ve XIX. yüzyılda Kafkasya, bölgede etkin olmak isteyen güçlerin mücadele alanı olmuştur. Bu bölge özellikle Osmanlı Devleti, İran ve Rusya bakımından stratejik önemini korumuştur. Bu sırada bölgede çeşitli bağımsız, yarı bağımsız ve bağımlı feodal Hanlıkların varlığı ortaya çıkmıştır. Her hanlık kendi şehri ve çevresinde etkili olduğu siyasi bir yapı oluşturup, birbirleriyle zaman zaman mücadele ederek ve çeşitli ittifaklara girişerek varlıklarını sürdürmüşledir. Karabağ toprakları daha Selçuklu döneminden başlayarak kadim bir

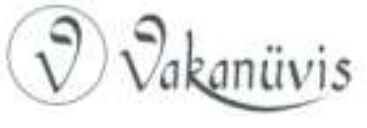


Türk yerleşme sahası olmuştur. Karabağ Hanlığı kurulmadan evvel, çevresiyle birlikte XVI. yüzyılda Osmanlı Devleti'nin etkisi altına girmeye başlamış ve III. Ahmet zamanında çevre kale ve şehirlerle Karabağ, Osmanlı Devleti'ne bağlanmıştır.

İdari bakımdan Azerbaycan'daki diğer hanlıklar gibi, Çıldır ve Erzurum Beylerbeyliği'ne bağlı olarak Osmanlı Devleti'yle bağlantısını sürdüren Karabağ, Osmanlı Devleti'nin bölgede etkinliğinin zayıflaması üzerine, İran ve Rusya arasında mücadele alanı olmaya başlamıştır. Bundan sonra bütün Kafkasya gibi Karabağ'da İki devletin Kafkasya ve Azerbaycan üzerinde şekillenen politikalardan etkilenmiştir. 1757 yılında bağımsızlığını İran'dan kazanan Penah Ali Han, Karabağ Hanlığını kurmuş ve uzun bir süre Hanlık, bağımsız olarak varlığını sürdürmüştür.

Karabağ Hanı olan gerek Penah Ali Han gerekse İbrahim Halil Han, Osmanlı Devleti'ne yakın politikalar izlemiş ve Osmanlı Devleti ile sürekli ilişki içinde olmak bir tarafa, devletin memurları gibi işbirliği içinde olmuşlardır. Ancak Osmanlı Devleti'nin gerileme ve zafiyet dönemlerine rastlayan yıllarda Karabağ Hanlığı ve diğer hanlıklara Osmanlı Devleti tarafından istenilen ölçüde gerekli destek verilememiştir.

Bu gelişmeler 1805 yılında Karabağ Hanı İbrahim Halil Han, Ruslara tabi olmayı kabul etmek zorunda kalmasından sonra Rus yönetiminin bölgedeki etkinliğinin artmasıyla başlamış, süreç devam ederek, 1813 tarihinde imzalanan Gülistan Antlaşması ${ }^{55}$ ve ardından imzalanan 1828

55 Gülistan Antlaşması, 12. Ekim 1813 tarihinde Rusya ile Kaçarlar (İran) arasında imzalanan antlaşmadır. Bu antlaşma sonucunda Güney Kafkasya 'da bulunan bereketli Karabağ toprakları Rusya yönetimine geçmiştir. İran adına antlaşmayı Abbas Mirza Kaçar'ın vekili olarak Mirza Abdulhasan Han Şirazi imzalamıştır. Bu antlaşmayla tarihte ilk kez Kuzey Azerbacan Rusya'ya bağlanmıştır. Güney Azerbaycan ise İran'da kalmıştır. Mevcut bölünme Türkmençay Antlaşmasıyla pekişmiş ve günümüze kadar devam etmiştir. Böylece Talış, Şirvan, Kuba, Bakü, Gence, Karabağ ve Şeki hanlıkları Rusya'ya katılmıştır. İran, Doğu Gürcistan'a, Kazak ve Şemseddil sultanlıklarına, ayrıca Dağıstan'a ait iddialarından vazgeçtiğini bildirmiştir. Revan ve Nahçivan hanlıkları ise İran hâkimiyetinde kalmıştır. Bu gelişmeler sonucunda Hazar Denizi'nde donanma bulundurma hakkı Rusya'ya ait olmuştur. Rus tacirler dâhili gümrük vergisinden muaf olarak ticaret yapabilmişlerdir.

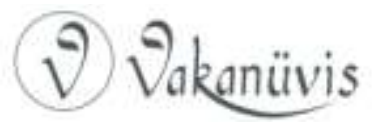


Türkmençay Antlaşması ile Azerbaycan toprakları, İran ve Rusya arasında paylaşılmıştır. Karabağ'ın kaderi de buna göre şekillenmiştir. Kuzey Azerbaycan, Rusya'nın etki alanı içine girmiş, Güney Azerbaycan da İran'a bırakılmıştır. Bunun soncunda Karabağ Hanlığı ve diğer hanlıklar ortadan kaldırılarak bir kısmının Ruslara, bir kısmının da İran'a bağlanması neticesinde Azerbaycan coğrafyasında uzun yıllar ve hatta günümüze kadar sürecek Rus ve İran etkinliğinin oluşmasına zemin hazırlanmıştır.

Bu şekilde hanlıkların ortadan kalkması ve Azerbaycan topraklarının Rusya ile İran arasında bölüşülmesinden sonra, 1828 Türkmençay Anlaşması sonucu Kafkasya'da, gerek İran ve gerekse Rusya arazisinde yaşayan halklar için istedikleri yere göç etme hakkı tanınmıştır. Rusya, İran tarafında yaşayan Ermenileri göçe teşvik etmek amacıyla bunlardan 30 yıl süreyle vergi almama kararı almış ve kendilerini vergiden muaf tutmuştur. Rus idaresi, İran'dan göç eden Ermenilerinki bunlar 70.000 civarındaydı- büyük bir kısmını başta Karabağ olmak üzere Erivan ve Nahcivan'a yerleştirmiştir. Böylece anılan yerlerde Ermeni nüfusu yoğunluk kazanmıştır. Bu sırada Karabağ nüfusunun bir kısmının Ermenilerden ibaret olması nedeniyle Azeri Türkleri ile Ermeniler arasında sert tartışmalar yaşanmış ve anlaşmazlıklar baş göstermiştir. ${ }^{56}$

Neticede, bir taraftan Revan, diğer taraftan Karabağ havalisine Rusya ve İran'daki Ermenilerin göç ettirilmesi, bunlara vergi muafiyetleri tanınarak buralara yerleştirilmeleri ile bu coğrafyada günümüze kadar devam edecek özellikle Karabağ üzerindeki AzeriErmeni anlaşmazlığının tohumları atılmış ve bir çatışma zemini hazırlanmıştır.

Ermenileri çeşitli siyasî yollarla Revan ve havalisine yerleştiren Ruslar, Osmanlı Devleti'nin içinde bulunduğu durumdan da faydalanarak, rahat hareket etme imkânı bulmuştur. Nitekim Rus Çarı Nikola, Ermenilerin yerleştirildiği bu sahada Erivan ve Nahcivan Hanlıkları topraklarını da içine alan bir Ermeni bölgesi oluşturmuştur. Rusya, böylece merkezi Erivan olan Ermenistan Sovyet Sosyalist Cumhuriyeti'nin temellerini atmıştır. Karabağ ve Azerbaycan toprakları

${ }^{56}$ Özçelik, Karabağ Tarihi ve Karabağ'da Ermeni Olayları, s.70-74.

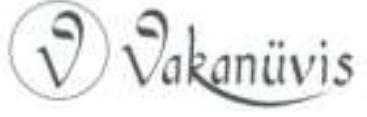


üzerinde zorla yaratılan bu Ermeni iskân bölgesiyle hem Azerbaycan ikiye bölünmüş hem de Rusya Osmanlı Devleti'ne karşı bir Ermeni tampon bölgesi oluşturmuştur. ${ }^{57}$

Bugün Ermenistan'ın hak iddia ettiği Karabağ'daki topraklara Ermenilerin XIX. yüzyılda yerleştirildikleri açıkça görülmektedir. Bu durum Türkistan ve Kafkaslarda uygulanan geleneksel Rus iskân siyasetimin bir sonucudur. Böylelikle, Anadolu'nun "Vilâyet-i Sitte" 58 diye adlandırılan bölgelerini de içine alacak Büyük Ermenistan idealinin temelleri atılmıştır. ${ }^{59}$

\section{Kaynakça}

Osmanlı Devleti Ile Azerbaycan Türk Hanlıkları Arasındaki Münâsebetlere Dâir Arşiv Belgeleri, (Karabağ-Şuşa, Nahçivan, Bakü, Gence, Sirvan, Seki, Revan, Kuba, Hoy), I, (1578-1914), Başbakanlık Devlet Arşivleri Genel Müdürlüğü Yayınları, Ankara, 1992.

Bala, Mirza, "Karabağ", İslam Ansiklopedisi, c.6, Milli Eğitim Bakanlı̆̆ı Yay., İstanbul, 1993.

Baykara, Hüseyin, Azerbaycan'da Yenileşme Hareketleri, Türk Kültürünü Araştırma Enstitüsü Yay., Ankara, 1966.

Budak, Mustafa, "Kafkasya ve Osmanlı Devleti, (XVI.-XX. Yüzyıllar)", Osmanlı Ansiklopedisi, c. 1, Yeni Türkiye Yay., Ankara, 1999.

Caferoğlu Ahmet, Azerbaycan, Bürhaneddin Yay., İstanbul, 1940.

Cevanşir, Ahmet Bey, Karabağ Hanlığının Tarihi, (hazırlayan Yusuf Gedikli), Selenga Yay., İstanbul, 1993.

Geybullayev, Gıyaseddin, Karabağ/ Etnik ve Siyasi Tarihine Dair, Bakü, 1990.

Gökçe, Cemal, Kafkasya ve Osmanlı Imparatorluğu'nun Kafkasya Siyaseti, Şamil Eğitim ve Kültür Yay., İstanbul, 1979.

\footnotetext{
${ }^{57}$ Özçelik, Karabağ Tarihi ve Karabağ'da Ermeni Olayları, s.77-78.

${ }^{58}$ Osmanlı Devleti'nin Altı Vilayeti olan Sivas, Mamurat'ül-aziz, Erzurum, Van, Bitlis ve Diyarbekir illeridir. O zamanki sınırları itibariyle Merzifon'dan Hakkâri'ye, Mardin'den Ağrı'ya kadar olmak üzere, i̇ç Anadolu, Doğu ve Güneydoğu Anadolu'yu da kapsayan geniş alan.

${ }^{59}$ Geniş bilgi için bkz. Sadi Koçaş, Tarih Boyunca Ermeniler ve Türk-Ermeni Ilişkileri, Türk Kültürünü Araştırma Enstitüsü, Yay., Ankara, 1967.
}

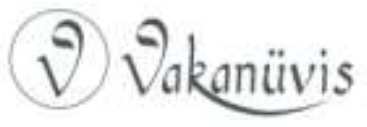


Kafalı, Mustafa, "Timur", Islam Ansiklopedisi, c.12, Milli Eğitim Bakanlığı Yay., İstanbul, 1993.

Kafesoğlu, İbrahim, Sultan Melikşah, Kültür Bakanlığı Yay., İstanbul, 1973.

Karabağlı, Mirza Cevanşir, Karabağ Tarihi, (çeviren Tahir Sümbül), Kök Sosyal ve Stratejik Araştırmalar Serisi: 4, Ankara, 1990.

Özçelik, İsmail, "Karabağ Kimindir?”, Kamu Çalışanları Aylık Mesleki Yorum Dergisi, Mayıs, Ankara, 1992.

Özçelik, İsmail, "Tarihin Işığında Karabağ”, Ankara Aydınlar Ocağı Bülteni, Ankara, 1996.

Özçelik, İsmail, Devlet-i Aliyye’nin Kamusal Düzeni ve Kurumları, Gazi Kitabevi, Ankara, 2014.

Özçelik, İsmail, Karabağ Tarihi ve Karabağ'da Ermeni Olayları, Bilge Yayınları, Ankara, 2003.

Özçelik, İsmail, Tarih ve Metodolojisi, Gazi Kitabevi, Ankara, 2014.

Özçelik, İsmail, Devlet-i 'Aliye'nin Taşra Yönetimi, Gazi Kitabevi, Ankara, 2016,

Taşkıran, Cemalettin, Geçmişten Günümüze Karabağ Meselesi, Genel Kurmay Basımevi, Ankara, 1995.

Togan, Zeki Velidi, "Azarbaycan”, İslam Ansiklopedisi, c. 2, Milli Eğitim Bakanlığı Yay., İstanbul, 1993.

Uzunçarşılı, İsmail Hakkı, Osmanlı Tarihi, Cilt 2, Türk Tarih Kurumu Yay., Ankara,1972.

Uzunçarşılı, İsmail Hakkı, Osmanlı Tarihi, Cilt. 3, Türk Tarih Kurumu Yay., Ankara, 1972.

Yıldırım, Dursun, Karabağ Dosyası, Türk Kültürünü Araştırma Enstitüsü Yayınları, Ankara, 1990. 